\title{
THE CONSTITUTIONALITY OF THE NEW YORK MUNICIPAL WAGE FREEZE AND DEBT MORATORIUM: RESURRECTION OF THE CONTRACT CLAUSE
}

\section{INTRODUCTION}

In the wake of New York City's recent fiscal crisis, the New York City Council passed legislation authorizing Mayor Beame to freeze the wages of municipal employees. The mayor signed the ordinance into law ${ }^{1}$ on August 1, 1975. Local Law 43 gave the mayor authority to promulgate an executive order suspending all or any part of increases in public employees' salaries or wages that either had taken effect or were to take effect at any time subsequent to June 30,1975 , pursuant to collective bargaining agreements requiring such salary increases as of July 1, 1975 or later. A similar provision applied to increased payments for holiday and vacation differentials and for salary adjustments. The ordinance exempted public employees who voluntarily agreed to a deferment of salary increases ihrough appropriate action by their certified collective bargaining representatives, and authorized the promulgation of an executive order terminating the suspensions of salary increases at the discretion of the mayor. ${ }^{2}$

Mayor Beame used this authority to roll back wages as of September $1,1975^{3}$ to the levels of June 30,1975 , for employees of those municipal unions that did not agree to a wage freeze voluntarily. This action wiped out a cost-of-living increase averaging $6 \%{ }^{4}$ that went into effect under existing union contracts on July 1. The mayor's order stipulated that the freeze for employees whose unions refused to agree voluntarily to the wagefreeze plan would continue until September 1, 1976. On the other hand, employees of unions that complied voluntarily were left in a somewhat better position. Under their agreement with

${ }^{1}$ New York, N.Y., Local Law 43, Aug. 1, 1975.

2 When the state legislature met in Extraordinary Session in September, 1975, it strengthened the mayor's hand by enacting a wage freeze virtually identical to the municipal one. New York State Financial Emergency Act for the City of New York, N.Y. UnConsol. Laws ch. 868 (McKinney Supp. 1975).

${ }^{3}$ N.Y. Times, Aug. 30,1975 , at 8 , col. 1 .

+ Id. 
the mayor, employees earning up to $\$ 10,000$ a year would keep two-thirds of the increase, employees earning up to $\$ 15,000$ would keep one-third, and those with salaries above $\$ 15,000$ would lose the increase entirely. ${ }^{5}$

In response to the city's growing fiscal crisis, on November 14, 1975, the state legislature passed the Emergency Moratorium Act. ${ }^{6}$ The Act provided for a three-year moratorium on enforcement of outstanding short-term notes due in 1975 and 1976, including tax anticipation notes, land anticipation notes, revenue anticipation notes, budget notes, and urban renewal notes. Instead of receiving their principal when due, the noteholders were offered two choices. First, the Act required that noteholders be given the opportunity to exchange their notes for Municipal Assistance Corporation (MAC) bonds in an equal principal amount. Pursuant to the terms of the Act, MAC, on November 26,1975 , offered to exchange its $8 \%$ bonds due in 1986 for city notes, ${ }^{7}$ although interest rates on the outstanding notes ranged up to $9.5 \% .^{8}$ Moreover, the Act provided that interest on notes that were not exchanged for MAC bonds would be paid until the date of maturity of the note, and that thereafter the notes were to be converted by law into notes due November 15,1978 , with $6 \%$ interest. In effect, noteholders who originally made one-year loans were now compelled to make additional three-year loans at a $6 \%$ interest rate, which is far below both the interest rate of their original notes and the present market rate for such notes. ${ }^{9}$

${ }^{5} I d$.

${ }^{6}$ New York State Emergency Moratorium Act for the City of New York, N.Y. Unconsol. Laws ch. 874 (McKinney Supp. 1975), as amended, N.Y. Unconsol. Laws ch. 875 (McKinney Supp. 1975).

${ }^{7}$ City "notes" are obligations with maturities of a year or less; "bonds" have maturities that are generally much longer.

Approximately $\$ 4.7$ billion worth of outstanding notes were affected by the moratorium, although the MAC bond exchange was only offered to holders of $\$ 1.6$ billion worth of notes. Flushing Nat'l Bank v. Municipal Assistance Corp., 84 Misc. 2d 976, 978-79, 379 N.Y.S.2d 978, 981-82 (Sup. Ct. 1975), aff'd, 52 App. Div. 2d 84, 382 N.Y.S.2d 764 (1976), appeal docketed, No. 392, Sept. Term, 1976. It appears that the exchange offer was not made to holders of approximately $\$ 3$ billion worth of city notes, including the state, MAC, the 11 New York Clearing House Banks, and certain city pension funds, all of whom waived their right to participate in the exchange. Brief for Respondent at 6-7, Flushing Nat'l Bank v. Municipal Assistance Corp., 52 App. Div. 2d 84, 382 N.Y.S.2d 764 (1976) [hereinafter cited as MAC Brief].

${ }^{8}$ Prospectus, Exchange Offer to Holders of Certain Short-Term Notes of the City of New York by the Municipal Assitance Corporation for the City of New York, Nov. 26, 1975, at 3 [hereinafter cited as MAC Prospectus].

${ }^{9}$ It is clear that the market interest rate for a similar note sold on the market would be significantly greater than $6 \%$. For example, on Oct. 17,1975 , the city sold to MAC a 
The New York Supreme Court and Appellate Division, in Flushing National Bank v. Municipal Assistance Corp. ${ }^{10}$ have upheld the Emergency Moratorium Act against a contract clause attack, and the Court of Appeals has granted a petition for review and heard argument. Relying on those decisions, the Special Term has upheld the wage freeze against a similar challenge. ${ }^{11}$ These decisions may have resolved the constitutional question for New York for the moment, but they have not adequately explored all the issues involved. Consequently, as a guide for courts that must deal with these problems in the future, this Comment will examine the constitutionality of the wage freeze and debt moratorium under the contract clause of the United States Constitution. ${ }^{12}$ A definitive judicial resolution of this constitutional issue may have an enormous future impact on municipalities, on those who contract with municipalities, and on the public at large. Certainly, any precedent established by such a resolution will be important to other municipalities that, in the future, have fiscal problems ${ }^{13}$ and wish to reduce unwanted financial obligations.

This Comment first will examine the history and policy of the contract clause, focusing on the nature of the contract and the contracting parties, and will conclude that the traditional contract clause doctrine should not apply when, as in the present situation, the state itself is a party to the contract being impaired, and the contract involves mutually beneficial terms, with the state incurring financial obligations. Consequently, it will be suggested that the two laws in question are unconstitutional ${ }^{14}$ in their present form. Finally, a framework will be proposed for a legislative solution that meets the contract clause requirements found to exist under this Comment's analysis. Before discussing the contract clause itself, however, it would be useful first to ex-

one-year note at $8.24 \%$. Moreover, city bonds maturing on Apr. 15, 1978, have been offered at a $17 \%$ yield to maturity and bid at a $22 \%$ yield. Brief for Appellant at 34-36, Flushing Nat'l Bank v. Municipal Assistance Corp., 52 App. Div. 2d 84, 382 N.Y.S.2d 764 (1976).

${ }^{10} 84$ Misc. 2d 976, 379 N.Y.S.2d 978 (Sup. Ct. 1975), aff'd, 52 App. Div. 2d 84, 382 N.Y.S.2d 764 (1976), appeal docketed, No. 392, Sept. Term, 1976. A federal district court recently upheld the Moratorium Act in Ropico, Inc. v. City of New York, 45 U.S.L.W. 2178 (S.D.N.Y., Sept. 3, 1976). The court rejected the plaintiff's contract clause claim using reasoning similar to that used by the Flushing courts.

${ }_{11}$ Subway-Surface Supervisors Ass'n v. Transit Auth., 85 Misc. '2d 695, 381N.Y.S.2d 186 (Sup. Ct. 1976).

12 U.S. ConsT. art. $1, \S 10$.

${ }^{13}$ See note 149 infra \& accompanying text.

${ }^{14}$ For a brief statement in support of the constitutionality of debt moratoriums, see Bremer, Memorandum on Municipal Debt Moratoriums, 32 Guild Practitioner 92 (1975). 
amine the policy debate underlying the wage freeze and debt moratorium controversies.

\section{A. The Policy Debate}

The constitutional issues raised by the wage freeze and debt moratorium laws cannot be understood fully without an examination of the policy considerations involved. Certainly the broad policy implications of any precedents set by these laws will greatly affect the ultimate resolution of the constitutional issues.

With regard to the wage freeze, the city argued that adverse economic conditions had produced a serious decline in the receipt of tax revenues and that inflation had greatly increased the cost to New York City of fuel, materials, and supplies far beyond the levels contemplated when recent wage contracts with muncipal unions had been signed. Because municipal tax increases would only precipitate an exodus of business concerns and the middle class from the city and thus would be unlikely to increase tax revenues, and because MAC had experienced difficulty in selling its bonds, the wage freeze was considered necessary for maintaining the city's fiscal integrity. The freeze was also justified by the need to convince investors that New York City was willing to take drastic steps to ensure that it would not default on its debt obligations. It was argued that only if fiscal credibility were restored and investors convinced that the city was ending its extravagant ways would the city be able to sell its bonds. ${ }^{15}$ Moreover, the wage reduction would allow the city to retain employees who otherwise would have to be fired to reduce expenses. Reduction of the municipal labor force would be undesirable because it would reduce the level of services the city could provide and increase the city's unemployment rate. The wage freeze would entail only a slight burden on all municpal employees, rather than the severe hardship of unemployment on those who would be fired. Finally, "outrageous" wage settlements, often precipitated by illegal union strikes, were said to be in large part responsible for the city's financial difficulties; therefore, the argument went, the municipal unions should be expected to play their part in the solution of the city's problems. This view was widely held while Local Law 43 was being debated. For example, a New York Times editorial regarding an illegal sanitation strike in protest of layoffs stated, "New York is working for its unionized civil service workers, not vice versa. The real 
power in the city is held by the municipal unions." 16

Union supporters countered that the wage freeze was an unnecessary and undesirable piece of legislation. For a city with an estimated borrowing need of about $\$ 8$ billion, the estimated savings of from $\$ 100-200$ million $^{17}$ realized by breaking labor contracts would hardly restore fiscal health to the city. Thus, the unions cited as the real force behind the legislation the desire of Wall Street and the city to find a scapegoat for their problems in the name of restoring investor confidence. ${ }^{18}$ The union leaders also questioned whether the city's union-blasting really would increase the sale of city bonds, noting that if the city could ignore its contractual obligations with employees, investors would realize that it could just as easily violate its commitments to its bondholders. ${ }^{19}$ Subsequent events that led to the debt moratorium are not inconsistent with this theory. It was also pointed out that the courts' validation of the city's actions could substantially weaken, if not destroy, the process of collective bargaining by demonstrating that one of the parties to a contract has the legal right to break it.

Furthermore, union supporters argued that the unions were unfairly being made scapegoats for the city's poor management. Procedures for collective bargaining exist under both state ${ }^{20}$ and city $^{21}$ law, and the unions should not be penalized for taking tough bargaining stances when they were entitled to do so. Contrary to popular belief, municipal employee wages, adjusted for the cost of living, were not significantly greater than those of employees in other major cities, ${ }^{22}$ and given the increases in the cost of living in the past year, municipal employees could hardly afford a pay cut. Moreover, New York City's fiscal crisis was the product of a host of factors, ${ }^{23}$ including serious financial mismanagement by city officials. ${ }^{24}$ In the wake of rising inflation,

${ }^{16}$ N.Y. Times, July 8, 1975, at 30 , col. 1.

${ }^{17}$ Id., Aug. 18, 1975, at 49, col. 3; id., Aug. 17, 1975, \& 4, at 5, col. 5.

${ }^{18}$ As Morton Bahr, a vice-president of the Communciation Workers of America argued: "We negotiated with the city in good faith .... We accepted what, in the face of inflation, is a substandard wage increase. Now, we are told that our contracts are so many meaningless pieces of paper that can be abrogated whenever the gods of Wall Street demand new sacrifices." Id., Aug. 18, 1975, at 49, col. 3.

${ }^{19} I d$., Aug. $17,1975, \S 4$, at 5 , col. 5 .

${ }^{20}$ N.Y. Civ. Serv. LAw $\$ \S 200-14$ (McKinney 1973) [hereinafter cited as Taylor Law].

212 CCH Lab. L. ReP., State Laws, N.Y. FI 47,450-50.18 (1972).

${ }^{22}$ N.Y. Times, June 22, 1975, $\$ 4$, at 7, col. 5; id., June 10, 1975, at 32, col. 1 .

${ }^{23}$ See note 150 infra.

${ }^{24}$ See note 154 infra \& accompanying text. 
union supporters argued, it is difficult to justify singling out one group of employees to bear a grossly disproportionate share of the city's financial burden. Finally, the unions argued, even if their members were better off with wage cuts than with layoffs, they should be able to resolve that issue voluntarily. The unions therefore objected to coercive wage freeze legislation that treated more harshly those who did not voluntarily come to terms than those who "voluntarily" agreed to the city's offer.

Policy considerations are also of great relevance to the courts' ultimate resolution of the debt moratorium controversy. That the fiscal situation of New York City at the time of the enactment of the Emergency Moratorium Act was grave can hardly be disputed. The legislative findings accompanying the Act argued compellingly for the need for state action, speaking of a "grave public emergency." 25 In the face of the unknown social, economic, and legal consequences of a default, and the previous, unsuccessful attempts by the city and state to stabilize the situation, ${ }^{26}$ the Flushing trial court, in rejecting the noteholders' contract clause argument, declared: "We must deal with this subject realistically in light of the financial crisis in the City."27 MAC thus argued that if the Act were declared unconstitutional, the city would be unable to pay either principal or interest on the outstanding notes, and noteholders would be forced to assert their claims in a municipal bankruptcy proceeding in which they would receive far less than the face value of

\footnotetext{
${ }^{25}$ [T] he grave public emergency . . has dramatically worsened in the last two months. Today, not only is the City of New York threatened with default on its outstanding obligations, but financially sound agencies of the state itself are similarly threatened because of public fears about the effects of default by the city.

Significant and drastic steps have been and continue to be taken by the city and the state .... It is now apparent, however, that there is not enough time for the effects of these steps to be demonstrated before all funds now available to the city will be exhausted.

There is therefore an imminent danger that the city of New York will be unable to pay its outstanding short-term indebtedness and even to provide those basic services essential to the health, safety and welfare of its inhabitants and the continuation of orderly government in the city. The legislature recognizes and insists that the pledge of the "faith and credit" of the city to the payment of its obligations must be respected. The legislature further recognizes that in the current financial crisis, this pledge can be honored only if the viability and resources of the city are preserved and that the continuation of essential services is vital to such preservation.
}

New York State Emergency Moratorium Act for the City of New York, N.Y. Unconsol. LAws ch. 874, 11 (McKinney Supp. 1975).

${ }^{26}$ See, e.g., Municipal Assistance Corporation for the City of New York, N.Y. Pub.

Aurh. LAw \$§ 3030-40 (McKinney Supp. 1975).

${ }^{27} 84$ Misc. $2 \mathrm{~d}$ at 978,379 N.Y.S.2d at 981 . 
their notes. ${ }^{28}$ The relevance of the policy factors in the New York courts' decisions was underscored by a revealing statement of the trial court indicating with approval its perception that "[t]he courts, Federal and State, have given priority to the public interest over strict compliance with the contract clause."29

On the other hand, it is clear that the debt moratorium sacrificed the financial interests of the noteholders by drastically altering their substantive rights. City noteholders who made short-term loans to avoid the risks of long-term investments were forced to make additional three-year loans at a $6 \%$ compensation rate, which bore no relation to the risk involved, the market interest rate, or the interest rate on their original notes. ${ }^{30}$ Even if the principal on all outstanding notes could not be repaid, there is no reason why prior noteholders should be singled out to subsidize interest payments on the outstanding notes. Moreover, many of the noteholders were small investors who may have had pressing needs for their principal. The New York trial judge recognized this problem when he stated: "I would urge-but I do not mandate- that provision be made to pay principal as the notes mature to those invidiuals who have invested $\$ 10,000$, or under, and who can show need for payment of their notes as they become due."31

Furthermore, bankruptcy would not follow inevitably if the courts were to declare the debt moratorium to be unconstitutional. The city, state, and federal governments, as well as banking institutions throughout the country, ${ }^{32}$ have substantial financial incentives for reaching a constitutional solution to the debt problem that accommodates the interests of all parties. If no such compromise is forthcoming, at a minimum the courts should scrutinize the legislative solution carefully to ensure that the financial interests of the noteholders are preserved to the greatest extent possible. For example, the courts could require that principal be paid to small investors when due, and when principal is withheld, the courts could require that interest rates reflect the cost to the noteholder of the forced investment.

${ }^{28}$ MAC brief, supra note 7, at 12 .

2984 Misc. $2 d$ at 979,379 N.Y.S.2d at 982.

${ }^{30}$ See note 9 supra \& accompanying text.

3184 Misc. $2 d$ at 984,379 N.Y.S.2d at 987.

32 The Federal Reserve Board has revealed the extent of bank holdings of New York obligations. Such obligations represent "more than 50 per cent of the capital of 234 banks in 29 states, and between 20 and 50 per cent of the capital of 718 banks in 33 states." N.Y. Times, Jan. 11, 1976, at 1, col. 2. Moreover, "the 11 major banks that make up the New York Clearing House held $\$ 3.97$ billion in obligations of the city and state." Wall St. J., Jan. 12, 1976, at 3, col. 4. 
Probably the most persuasive policy argument for holding the debt moratorium unconstitutional is the potential effect of a contrary ruling on municipal bond markets. If this attempted repudiation by the state of the city's financial obligations is sanctioned by the courts, other local governments that are experiencing financial difficulties may find it increasingly difficult to market their debt obligations at any interest rate, regardless of "promises" or "guarantees" made to potential purchasers. ${ }^{33}$

Finally, it must be realized that one of the original purposes of the contract clause ${ }^{34}$ was to protect the vested rights of individuals from state interference, even interference for "noble" purposes. While the United States Supreme Court's interpretation of the contract clause has changed dramatically over the years, ${ }^{35}$ it is clear that the clause is not without meaning. ${ }^{36}$ The rights of bondholders should not be ignored merely because their financial interests may not be as important as those that the Moratorium Act seeks to protect. Such a balance is inappropriate for constitutional adjudication, yet the Flushing trial judge concluded his opinion by stating: "I began by urging a realistic view of this controversy. I meant no more than to urge an equitable view that would do justice to the greatest number."37 While policy considerations and the interests of the majority are relevant to constitutional adjudication, ultimately the courts are responsible for interpreting the Constitution and protecting the rights of individual citizens regardless of whether those individual interests are contrary to the interests of the majority. As the New York Court of Appeals stated after finding the state constitution's "non-impairment" pension provision indirectly impaired by legislation mandating that the state comptroller, in his capacity as trustee, invest pension funds in MAC bonds:

The duty of a neutral court is clear even when it be utterly understanding of the extraordinary and troubled efforts by the officials of New York City, the State administration and the Legislature. As this court said in Bimbaum v. New York State Teachers Retirement System, 5 N.Y.2d 1, 11, 176 N.Y.S.2d 984, 992, 152 N.E.2d 241,

${ }^{33}$ The implications for bond markets of upholding the moratorium legislation are discussed in detail at text accompanying notes 143-47 infra. For a discussion of the financial condition of other cities, see note 149 \& text accompanying notes 149-52 infra.

${ }^{34} \mathrm{See}$ text accompanying note 43 infra.

${ }^{35}$ See text accompanying notes 39-70 infra.

${ }^{36}$ See text accompanying notes 71-72, 119-71 infra.

${ }^{37} 84 \mathrm{M}$ isc. 2d at 985,379 N.Y.S.2d at 987 (emphasis supplied). 
247 , in a context converse to that here but involving identical principles: "[The retirement system] argues that if this court [so] holds .. . the system will be plunged into bankruptcy. The answer to that argument must be that ... we are not at liberty to hold otherwise."

Indeed, it should be said that that is the primary role of the courts in the American system in reviewing the constitutional validity of executive and legislative acts even if they bear the guise, and the courts are convinced that the guise reflects a reality, of necessity, distress and emergency. The courts did not make the Constitution; the courts may not unmake the Constitution. ${ }^{38}$

\section{The Contract Clause}

\section{A. Early History}

The historical development of the contract clause ${ }^{39}$ of the Federal Constitution has been the subject of much commentary ${ }^{40}$ and does not warrant extensive treatment in this Comment. A brief discussion of that history is useful, however, in understanding the constitutional framework relevant to the New York wage freeze and debt moratorium. Although the framers of the Constitution apparently did not regard the contract clause with much concern, ${ }^{41}$ and consequently did not devote much time to consideration of the clause, ${ }^{42}$ it is fairly clear that the clause was a response to the mass of debtor relief legislation, which was passed by state legislatures in the wake of the economic depression immediately preceding the adoption of the Constitution, and which impaired contractual obligations. ${ }^{43}$ The clause was (1975).

${ }^{38}$ Sgaglione v. Levitt, 37 N.Y.2d 507, 514, 337 N.E.2d 592, 596, 375 N.Y.S.2d 79, 85

${ }^{39}$ U.S. Consr. art. I, § 10: "No State shall ... pass any . . Law impairing the Obligation of Contracts ...."

${ }^{40}$ For the best discussion of that development, see B. WRight, The Contract Clause of the Constitution (1938). See also El Paso v. Simmons, 379 U.S. 497, 517-35 (1965) (Black, J., dissenting); Home BIdg. \& Loan Ass'n v. Blaisdell, 290 U.S. 398, 448-83 (1934) (Sutherland, J., dissenting); B. Schwartz, A Commentary on the Constitution of the United States, The Rights of Property (1965); Hale, The Supreme Court and the Contract Clause, 57 Harv. L. Rev. 512 (1944); Note, The Contract Clause of the Federai Constitution, 32 Colum. L. Rev. 476 (1932); Note, Constitutionality of Mortgage Relief Legislation: Home Building \& Loan Ass'n v. Blaisdell, 47 HARv. L. Rev. 660 (1934); 40 S. CAL. L. Rev. 576 (1967).

${ }^{41}$ See B. WRIGHT, supra note 40 , at 5, 14-15.

${ }^{42}$ See Home Bldg. \& Loan Ass'n v. Blaisdell, 290 U.S. 398, 427 (1934); B. WRIGHT, supra note 40 , at 5-16.

${ }^{43}$ See B. Wright, supra note 40, at 4-6; Home Bldg. \& Loan Ass'n v. Blaisdell, 290 U.S. 398, 427 (1934); id. at 454-64 (dissenting opinion). 
intended originally to deal with private contracts, and there is little indication that contracts to which a state is a party were intended to fall within its prohibition. ${ }^{44}$ Chief Justice Marshall, however, who was in large part responsible for the broad interpretation given the contract clause during the nineteenth century, ${ }^{45}$ did read the clause to apply to contracts between an individual and the state in Fletcher $v$. Peck. ${ }^{46}$ Further expansive interpretation of the doctrine by the Marshall Court turned the clause into the most important restraint on state interference with property rights prior to the due process clause of the fourteenth amendment. ${ }^{47}$ Almost half of all decisions before 1889 in which state legislation was declared invalid by the Court were based on the contract clause. ${ }^{48}$

The decline of the importance of the contract clause in the early twentieth century ${ }^{49}$ paralleled the rise of the "inalienable police power" doctrine ${ }^{50}$ and the practice of upholding state economic regulation under substantive due process as long as the regulation was "reasonable" and "not arbitrary." 11 The early transitional contract clause cases applying the police power doctrine can be grouped into two classes. First, there were cases involving contracts between private persons in which the subject matter of the contract was of unusual public importance. ${ }^{52}$ The

\footnotetext{
44 See B. Wright, supra note 40, at 15-16, 32-33; Merrill, Application of the Obligation of Contract Clause to State Promises, 80 U. PA. L. Rev. 639 (1932).

${ }^{45}$ See B. Wright, supra note 40, at 26-61. For examples of Chief Justice Marshall's contract clause decisions, see Dartmouth College v. Woodward, 17 U.S. (4 Wheat.) 518 (1819); Sturges v. Crowninshield, 17 U.S. (4 Wheat.) 122 (1819); New Jersey v. Wilson, 11 U.S. (7 Cranch) 164 (1812); Fletcher v. Peck, 10 U.S. (6 Cranch) 87 (1810).

${ }^{46} 10$ U.S. (6 Cranch) 87 (1810). In Fletcher, the Court held that a public land grant constituted a contract between a state and the grantees of the public land, and that a statute repealing the grant was consequently an unconstitutional impairment of the obligation of the contract.

${ }^{47}$ See B. WRIGHT, supra note 40, at 95-97; Note, The Contract Clause of the Federal Constitution, 32 Colum. L. Rev. 476 (1932); 40 S. CaL. L. Rev. 576 (1967).

${ }^{48} \mathrm{~B}$. WRIGHT, supra note 40 , at 95.

${ }^{49}$ Id. 96-97.

${ }^{50}$ See $2 \mathrm{~T}^{-}$. Cooley, Constitutional Limitations 1223-348 (8th ed. 1927); B. WRIGHT, supra note 40, at 196-213; Hale, supra note 40, at 654-63, 872-84; Merrill, supra note 44 , at $657-67$.

${ }^{51}$ For a leading case heralding the decline of judicial intervention in economic regulation, see Nebbia v. New York, 291 U.S. 502 (1934), in which the Court announced that if laws passed "have a reasonable relation to a proper legislative purpose, and are neither arbitrary nor discriminatory, the requirements of due process are satisfied ...."Id. at 537. The Court's noninterventionist stance in economic due process cases became more pronounced in later years. See, e.g., Williamson v. Lee Optical Co., 348 U.S. 483 (1955) (announcing that state economic regulations will not be struck down if "there is an evil at hand for correction, and ... it might be thought that the particular legislative measure was a rational way to correct it." $I d$. at 488 (emphasis supplied)).

${ }^{52}$ See, e.g., Henderson Co. v. Thompson, 300 U.S. 258 (1937) (statute prohibiting
} 
Court, in upholding legislation that interfered with private contract rights, reasoned that "one whose rights, such as they are, are subject to state restriction, cannot remove them from the power of the state by making a contract about them. The contract will carry with it the infirmity of the subject matter."53

The second group of cases involved contracts with the state, which, if ruled inviolable, would constitute a surrender by the state of its police power to protect the public health, morals, and safety. The majority of these cases involved state licensing. For example, in Stone v. Mississippi, ${ }^{54}$ the Court held that the grant of a twenty-five-year charter to operate a lottery was subject to later application of the police power and did not bar a subsequent law prohibiting lotteries: "All agree that the legislature cannot bargain away the police power of a State."55 In this class of cases, instead of holding that any contract impairment was justifiable, the Court seemed to interpret the contract to include an implied agreement that any privilege granted by the state was subject to the exercise of police power:

Any one ... who accepts a lottery charter does so with the implied understanding that the people ... may resume it at any time when the public good shall require .... He has in legal effect nothing more than a license to enjoy the privilege on the terms named for the specified time, unless it be sooner abrogated by the sovereign power of the State. ${ }^{56}$

certain uses of natural gas for conservation purposes upheld although statute prevented performance of company's contract with producers); Manigault v. Springs, 199 U.S. 473 (1905) (state legislation impairing a private contract involving control of a public waterway upheld in order to allow the state to clear a swamp). See also Stone v. Farmers' Loan \& Trust Co., 116 U.S. 307, 325-26 (1886); West River Bridge Co. v. Dix, 47 U.S. (6 How.) 507 (1848).

${ }_{53}$ Hudson County Water Co. v. McCarter, 209 U.S. 349, 357 (1908) (Holmes, J.).

54101 U.S. 814 (1879).

${ }^{55}$ Id. at 817; see Douglas v. Kentucky, 168 U.S. 488, 497-99 (1897). See also Pierce Oil Corp. v. City of Hope, 248 U.S. 498 (1919) (restrictions imposed on the storage of oil for public safety would not impair the obligation of contract); Fertilizing Co. v. Hyde Park, 97 U.S. 659 (1878) (franchise to carry fertilizer in the street may be repealed to ensure the public health); Beer Co. v. Massachusetts, 97 U.S. 25, 32-33 (1877) (corporate charter to manufacture beer must be read to imply that charter is subject to exercise of the police power, and law prohibiting manufacture of beer for health and moral reasons is constitu: tional). But see Walla Walla v. Walla Walla Water Co., 172 U.S. 1 (1898) (city's police power could not be invoked to abrogate contract with private firm to supply water to city, where contract was carried out with due regard for health and good order of city and its inhabitants).

${ }^{56}$ Stone v. Mississippi, 101 U.S. 814, 821 (1879) (emphasis supplied). 


\section{B. The Modern Police Power Doctrine}

The seminal case in the development of the police power doctrine as a justification for direct impairment of contracts is Home Building \& Loan Association v. Blaisdell. ${ }^{57}$ The Minnesota statute under consideration authorized judicial relief from mortgage foreclosures during the depression emergency. In sustaining the law as a valid exercise of the state's police powers, the Court gave great deference to the legislative judgment that an emergency existed ${ }^{58}$ and, in sweeping language, announced the rule that if "the legislation is addressed to a legitimate end and the measures taken are reasonable and appropriate to that end,"59 the exercise of police power will be sustained notwithstanding impairment of contract obligations. ${ }^{60}$ In addition, the Court suggested that the economic interests of the state may justify such an exercise of the police power, because contracts between individuals often profoundly affect society as a whole:

Where, in earlier days, it was thought that only the concerns of individuals or of classes were involved, and that those of the State itself were touched only remotely, it has later been found that the fundamental interests of the State are directly affected; and that the question is no longer merely that of one party to a contract as against another, but of the use of reasonable means to safeguard the economic structure upon which the good of all depends. ${ }^{61}$

Thus,

the reservation of essential attributes of sovereign power [must be] read into contracts as a postulate of the legal order. The policy of protecting contracts against impairment presupposes the maintenance of a government by virtue of which contractual relations are worth while,-a government which retains adequate authority to secure the peace and good order of society. ${ }^{62}$

Finally, the Court stated that "[w]hile emergency does not create power, emergency may furnish the occasion for the exercise of

57290 U.S. 398 (1934).

${ }^{58}$ Id. at $421-23$.

${ }^{59} \mathrm{Id}$. at 438 .

60 Note the similarity of this test to that used for economic due process. See note 51 supra.

61290 U.S. at 442.

${ }^{62} \mathrm{Id}$. at 435. 
power."63

Blaisdell marked a significant departure from the previous police power cases ${ }^{64}$ in which the nature or subject matter of the contract justified its impairment. Here, external depression conditions brought a contract, normally thought to involve only the property rights of individuals, within the scope of the police power. ${ }^{65}$

Post-Blaisdell commentators generally agree that the contract clause has largely been subsumed in the "rational relation" test used in fourteenth amendment substantive due process decisions, ${ }^{66}$ and some even question whether the clause has any meaning independent of due process. ${ }^{67}$ Although Blaisdell and subsequent cases relying on its reasoning ${ }^{68}$ have been criticized severely in two well-reasoned opinions ${ }^{69}$ for ignoring the explicit language of the contract clause, the Court's tendency to place the clause within the due process framework is certainly

${ }^{63} I d$. at 426.

${ }^{64}$ See cases cited notes 52-55 supra.

${ }^{65}$ See B. WRIGHT, supra note 40 , at 212-13.

The reasonableness test of Blaisdell was illuminated further in East New York Savings Bank v. Hahn, 326 U.S. 230 (1945). In that case the act in question was the tenth renewal of an act that put a year-long moratorium on private default actions for failure to pay the premium on a mortgage. Justice Frankfurter, in an opinion that gave great deference to the legislature's declaration of emergency, stated that the legislation reflected "[ $[$ ] he empiric process of legislation at its fairest: frequent reconsideration, intensive study of the consequences of what has been done, readjustment to changing conditions, and safeguarding the future on the basis of responsible forecasts." Id. at 234-35.

${ }^{66}$ B. Wright, supra note 40, at 258-59; Note, The Contract Clause of the Federal Constitution, 32 Colum. L. Rev. 476, 478-79 (1932); 40 S. CAL. L. Rev. 576, 589 (1967). The term "rational relation" is used as shorthand for the deferential test applied by the Court in its economic due process cases since 1934. See note 51 supra.

One apparent alternative to a rational basis test is a "balancing" approach. $C f$. El Paso v. Simmons, 379 U.S. 497 (1965) (Justice Black's dissent suggested that majority may have used a balancing approach. Id. at 517). Such an approach, however, affords little more than the minimal scrutiny of the rational basis test. If the courts balance the state interests against the interest of the contracting parties, they inevitably will find for the state. See, e.g., text accompanying notes $37-38$ supra. Thus, a more specific test should be adopted. See text accompanying notes 225-34 infra.

${ }^{67}[\mathrm{~T}]$ he results might be the same if the contract clause were dropped out of the Constitution, and the challenged statutes all judged as reasonable or unreasonable deprivations of property." Hale, supra note 40, at 890-91; see B. SchwarTz, supra note 40, at 268-69.

${ }^{68}$ See, e.g., East New York Savings Bank v. Hahn, 326 U.S. 230 (1945); Veix v. Sixth Ward Ass'n, 310 U.S. 32 (1940); Farrell v. Drew, 19 N.Y.2d 486, 227 N.E.2d 824, 281 N.Y.S.2d 1 (1967); In re Dep't of Bldgs. of N.Y., 14 N.Y.2d 291, 200 N.E.2d 432, 251 N.Y.S.2d 441 (1964); Totten v. Saionz, 38 App. Div. 2d 630, 327 N.Y.S.2d 55 (Sup. Ct. 1971).

${ }^{69}$ W.B. Worthen Co. v. Thomas, 292 U.S. 426, 434 (1934) (Sutherland, J., concurring); Home Bldg. \& Loan Ass'n v. Blaisdell, 290 U.S. 398, 448 (1934) (Sutherland, J., dissenting). 
understandable. Contract rights are merely one form of property rights, and although it is true that an interest in a contract may be of equal importance to an individual as, for instance, an ownership interest in real property, in most cases there is no basis for treating contract rights with greater deference than that given to ownership interests. For example, it would be anomalous for the Court, when faced with legislation restricting the use of individual property, to uphold the legislation under the due process clause as reasonably related to a legitimate public purpose, only to have the legislation frustrated when individuals contracted concerning the use of the property. As the First Circuit recently noted: "An otherwise valid governmental regulation does not become impermissible merely because an object of the regulation is a party to some contracts. Nor can a party make otherwise unlawful action permissible merely by making a contract about it."70 This is not to say, however, that the contract clause has no meaning distinct from due process. For one thing, the clause was invoked successfully a number of times soon after Blaisdell. ${ }^{71}$ Although the same results might have been reached under the due process clause, the Court's use of the contract clause attests to its continued viability. Moreover, the contract clause may compel a much different analysis than that afforded by economic due process when the state is a party to the contract at issue. ${ }^{72}$

\section{The Wage Freeze and Debt Moratorium as Valid Exercises of the Police Power}

The argument that the wage freeze and debt moratorium constituted valid exercises of the police power, notwithstanding contract impairment, is a powerful one. Each piece of legislation was prefaced by a declaration of emergency that detailed the facts warranting the emergency action; ${ }^{73}$ such declarations are generally entitled to great respect. ${ }^{74}$ Even without giving defer-

${ }^{70}$ South Terminal Corp. v. Environmental Protection Agency, 504 F.2d 646, 680 (1st Cir. 1974).

${ }^{71}$ See, e.g., Treigle v. Acme Homestead Ass'n, 297 U.S. 189 (1936); W.B. Worthen Co. v. Kavanaugh, 295 U.S. 56 (1935); W.B. Worthen Co. v. Thomas, 292 U.S. 426 (1934); $c f$. Indiana ex rel. Anderson v. Brand, 303 U.S. 95 (1938); Lynch v. United States, 292 U.S. 571 (1934).

72 See text accompanying notes $119-71$ infra.

${ }^{73}$ See New York, N.Y., Local Law 43 \& 1173-12.0(a), Aug. 1, 1975; note 25 supra.

${ }^{74}$ East New York Savings Bank v. Hahn, 326 U.S. 230, 234-35 (1945); Home Bldg. \& Loan Ass'n v. Blaisdell, 290 U.S. 398, 444 (1934); Jacobson v. Massachusetts, 197 U.S. 11, 31 (1905); I.L.F.Y. Co. v. Temporary State Hous. Rent Comm'n, 10 N.Y.2d 263, 269, 
ence to these legislative findings of fact, one cannot dispute that the financial situation of New York City at the time was grave. The Blaisdell Court stated that the "economic interests of the State may justify the exercise of its [police power] notwithstanding interference with contracts."75 Accordingly, the city's economic interest in avoiding default on its obligations and the consequent economic chaos would seem to constitute a sufficient basis for a wage freeze designed to save revenue and restore creditor confidence. ${ }^{76}$ The desire to maintain economic stability within the city through a wage freeze certainly seems to be a "legitimate end" accomplished by "reasonable means" appropriate to that end under the Blaisdell test, ${ }^{77}$ especially when impairment of the wage contract obligations might be necessary to ensure the city's continued ability to fund public health, safety, and welfare programs. Likewise, the state's interest in avoiding the city's bankruptcy, with its uncertain legal, political, and economic repercussions, would seem to be a sufficient constitutional basis for the debt moratorium.

Even in cases with showings of less dire circumstances, the courts have cited Blaisdell to sustain economic regulations that interfered with existing contracts. For example, a United States district court, in sustaining the constitutionality of the wage control portions of the Economic Stabilization Act of $1970,{ }^{78}$ stated:

[A] solid, stable economy is one of the most vital interests which any Government must safeguard for its people. The Supreme Court has held again and again that economic conditions may arise in which a temporary restraint of the enforcement of certain contracts will be consistent with the purpose and spirit of the contract clause and thus well within the range of the

176 N.E.2d 822, 825, 219 N.Y.S.2d 249, 252 (1961), appeal dismissed, 369 U.S. 795 (1962); Lincoln Bldg. Associates v. Barr, 1 N.Y.2d 413, 135 N.E.2d 801, 153 N.Y.S.2d 633 (1956), appeal dismissed, 355 U.S. 12 (1957).

${ }^{75} 290$ U.S. at 437.

${ }^{76}$ As noted in the emergency declaration, New York, N.Y., Local Law 43 $\S 1173-12.0$ (a), tax increases were not a viable alternative for raising funds because such increases would likely precipitate an exodus of business concerns and middle class residents from the city, thereby decreasing the tax base. It was also noted that the Municipal Assistance Corporation had experienced difficulty in selling its bonds and that the wage freeze was therefore necessary to convince investors that the city was ending its profligate ways and was determined to restore fiscal credibility. See, e.g., N.Y. Times, July 29, 1975, at 1, col. 8; id., July 21, 1975, at 1, col. 8; id., July 18, 1975, at 1, col. 1.

${ }^{77}$ See text accompanying notes 57-60 supra.

${ }^{78}$ Act of Aug. 15, 1970, Pub. L. No. 91-379, tit. Il, 84 Stat. 799, as amended, Pub. L. No. $92-15, \S 3,85$ Stat. 38 (1971). 
reserved power of a government to protect the interests of its people. ${ }^{79}$

The Court of Appeals of New York, in In re Department of Buildings ${ }^{80}$ upheld a 1962 receivership law ${ }^{81}$ as reasonable and appropriate to combat the housing emergency that was found to exist, despite the law's impairment of existing landlord-tenant contract rights. Other cases have reached similar results. ${ }^{82}$

With regard to the debt moratorium, the United States Supreme Court, in Faitoute Iron $\mathcal{E}^{3}$ Steel Co. v. City of Asbury Park, ${ }^{83}$ upheld the constitutionality of a plan negotiated under a New Jersey insolvency statute that authorized an adjustment of creditors' claims against an insolvent municipality in those instances in which the adjustment plan had received prior approval by the municipality, by the state Municipal Finance Commission, and by creditors representing $85 \%$ of the indebtedness affected, and had been adopted under conditions prescribed by the state supreme court. The New Jersey legislation had been enacted to "meet the public emergency arising from a default in the payment of municipal obligations," 84 and the plan, which ultimately was approved by the state court, required conversion of bonds issued in 1929 and 1930 into bonds maturing in 1966 and bearing a lower interest rate than the original bonds. Rejecting a contract clause attack by bondholders who did not accept the statutorily authorized plan, the Court stated: "The notion that a city has unlimited taxing power is, of course, an illusion. A city cannot be taken over and operated for the benefit of its creditors, nor can its creditors take over the taxing power." 85 Furthermore, the Court noted that the practical value of an un-

${ }^{79}$ California Teachers Ass'n v. Newport Mesa Unified School Dist., 333 F. Supp. 436, 444 (C.D. Cal. 1971) (footnotes omitted). Note that although the contract clause does not apply to the federal government, the court stated that there was no unconstitutional impairment of contract rights even assuming that a similar prohibition could be inferred from the due process clause of the fifth amendment. Id. at 444.

${ }^{80} 14$ N.Y.2d 291, 200 N.E.2d 432, 251 N.Y.S.2d 441 (1964).

${ }^{81}$ N.Y. Mult. Dwell. Law $\S 309(5)$ (McKinney 1974). The law gave the city authority to curtail rent payments to landlords as a means of inducing them to eliminate dangerous housing conditions.

${ }_{82}^{82 e}$, e.g., Veix v. Sixth Ward Ass'n, 310 U.S. 32 (1940); Totten v. Saionz, 38 App. Div. 2d 630, 327 N.Y.S.2d 55 (Sup. Ct. 1971); Security Unit Employees, Council 82, AFSCME v. Rockefeller, 76 Misc. 2d 435, 351 N.Y.S.2d 348 (Sup. Ct. 1974).

${ }^{83} 316$ U.S. 502 (1942). Asbury Park is considered more fully in text accompanying notes 217-24 infra, where it serves as a basis for a proposed solution to municipal fiscal problems that better satisfies constitutional requirements than do measures such as New York's wage freeze and debt moratorium.

${ }^{84} \mathrm{Id}$. at 504.

${ }^{85} \mathrm{Id}$. at 509 . 
secured claim against the city depends upon the city's taxing power:

The only remedy for the enforcement of such a claim is a mandamus to compel the levying of authorized taxes. The experience of the two modern periods of municipal defaults, after the depressions of '73 and '93, shows that the right to enforce claims against the city through mandamus is the empty right to litigate. ${ }^{86}$

The state legislation, which ensured that the contract obligation "is discharged, not impaired," 87 was held to be constitutional, because "to deny a State the means of giving substance to the taxing power which alone gives meaning to unsecured municipal obligations, is to hold, in effect, that the right to pursue a sterile litigation is an 'obligation' protected by the Constitution of the United States." 88 Finally, after referring to the police power with respect to private bodies, the Court explicitly recognized that "a State should certainly not be denied a like power for the maintenance of its political subdivisions." 89

The New York courts relied heavily on expansive language from Asbury Park and Blaisdell to uphold the Moratorium Act in Flushing National Bank v. Municipal Assistance Corp. ${ }^{90}$ The Appellate Division's opinion began by noting that the Moratorium Act "was not enacted by the Legislature arbitrarily or in a vacuum

"91 After discussing the emergency situation, the court concluded that the Act merely modified the noteholders' contract remedy by revising the "schedule for payment of these obligations" 92 without impairing substantial rights secured by the contract. $^{93}$ In such circumstances, the court found that "the reasonableness of the modification of the remedy must be left to

${ }^{86} I d$. at 510.

${ }^{87}$ Id. at 511 .

${ }^{88} I d$. at 510-11.

${ }^{89} \mathrm{Id}$. at 513-14.

${ }^{90} 84$ Misc. 2d 976, 379 N.Y.S.2d 978 (Sup. Ct. 1975), aff'd 52 App. Div. 2d 84, 382 N.Y.S.2d 764 (1976), appeal docketed, No. 392, Sept. Term, 1976. The plaintiffs in Flushing also alleged other state and federal constitutional violations and violation of the Federal Bankruptcy Act. This Comment is concerned only with the alleged violation of the contract clause. It should be noted that the New York wage freeze also was upheld, in Subway-Surface Supervisors Ass'n v. Transit Auth., 85 Misc. 2d 695, 381 N.Y.S.2d 186 (Sup. Ct. 1976).

${ }^{91} 52$ App. Div. 2 d at 86,382 N.Y.S.2d at 766 (emphasis supplied).

${ }^{92} I d$. at 87,382 N.Y.S.2d at 767 .

${ }^{93}$ The distinction between modifying the remedy and impairing substantial rights is a tenuous one that may no longer be valid. See note 229 infra \& accompanying text. 
the judgement and discretion of the Legislature, which discretion should not be disturbed absent palpable error." the court never explicitly articulated its standard of review, the language quoted above suggests a more liberal standard than the Blaisdell "reasonable and appropriate" test. ${ }^{95}$ Quoting at length from Asbury Park, the court concluded its discussion of the contract clause by stating that the police power applies with equal force to both private and public obligations. ${ }^{96}$

\section{A Narrower Reading of the Police Power Doctrine}

Despite the broad language in Blaisdell concerning the proper use of the police power, it is not altogether clear that the Blaisdell line of cases is applicable to the New York City situation. The facts of Blaisdell and language not normally cited in cases upholding legislation under the police power support a narrower interpretation of the case than that outlined above. ${ }^{97}$ Indeed, a group of Supreme Court cases following Blaisdell, in which the Court invoked the contract clause to declare legislation unconstitutional, in fact applied a narrower interpretation..$^{98} \mathrm{Fi}$ nally, while the Blaisdell line of cases generally has dealt with state legislation concerning contracts between individuals, the New York wage freeze and debt moratorium apply to contracts to which the city is a party. Sound logic and some case law support the proposition that state legislation impairing the obligations of the state's own contracts should be treated differently than legislation involving purely private contracts. ${ }^{99}$ Although the courts have upheld some legislation affecting contracts to which the state is a party, ${ }^{100}$ these cases are distinguishable from the present situation, ${ }^{101}$ and, under certain circumstances, state legislation impairing the obligation of the state's own contracts is probably unconstitutional. ${ }^{102}$

The Blaisdell Court gave great weight to the fact that the

${ }^{94} 52$ App. Div. 2d at 87,382 N.Y.S.2d at 767 (emphasis supplied) (citations omitted).

${ }^{95}$ See text accompanying notes 58-60 supra.

${ }^{96} 52$ App. Div. $2 d$ at $88-89,382$ N.Y.S.2d at 767.

${ }^{97}$ See text accompanying notes 57-96 supra.

${ }^{98}$ See text accompanying notes 106-18 infra; Treigle v. Acme Homestead Ass'n, 297 U.S. 189 (1936); W.B. Worthen Co. v. Kavanaugh, 295 U.S. 56 (1935); W.B. Worthen Co. v. Thomas, 292 U.S. 426 (1934); $f f$. Indiana ex rel. Anderson v. Brand, 303 U.S. 95 (1938).

${ }^{99}$ See text accompanying notes 119-213 infra.

${ }^{100}$ See note 55 supra; El Paso v. Simmons, 379 U.S. 497 (1965); Faitoute Iron \& Steel

Co. v. City of Asbury Park, 316 U.S. 502 (1942).

${ }^{101}$ See text accompanying notes 155-70 infra.

${ }^{102}$ See text accompanying notes 123-54 infra. 
statute at issue was drawn narrowly to ensure that the interests of creditors would be protected. Thus the Court stressed that " $[t]$ he Act is to remain in effect 'only during the continuance of the emergency and in no event beyond May 1, 1935." "103 More importantly, the Court stated:

The statute does not impair the integrity of the mortgage indebtedness. The obligation for interest remains. The statute does not affect the validity of the sale or the right of a mortgagee-purchaser to title in fee, or his right to obtain a deficiency judgment, if the mortgagor fails to redeem within the prescribed period. Aside from the extension of time, the other conditions of redemption are unaltered. While the mortgagor remains in possession he must pay the rental value .... While the mortgagee-purchaser is debarred from actual possession, he has, so far as rental value is concerned, the equivalent of possession during the extended period. ${ }^{104}$

The Court also noted that the police power of the state "must be consistent with the fair intent of the constitutional limitation of that power. The reserved power cannot be construed so as to destroy the limitation ...."105

Although Blaisdell clearly was not intended as a mere extension of the doctrine that a state may enact laws modifying a contractual remedy, ${ }^{106}$ subsequent decisions restricting its holding ${ }^{107}$ leave open to question its applicability in the $\mathrm{New}$ York situation. ${ }^{108}$ In W.B. Worthen Co. v. Thomas, ${ }^{109}$ the Court, in holding legislation not limited to the Depression emergency to be unconstitutional, stated that the principles of Blaisdell "precluded a construction which would permit the State to adopt as its policy the repudiation of debts or the destruction of contracts or the denial of means to enforce them."110 Two years later, in W.B. Worthen Co. v. Kavanaugh, ${ }^{111}$ Justice Cardozo distinguished

${ }^{103} 290$ U.S. at 416.

${ }^{104} \mathrm{Id}$. at 425.

${ }^{105} I d$. at 439.

${ }^{106}$ See Von Hoffman v. City of Quincy, 71 U.S. (4 Wall.) 535, 553-54 (1867); Sturges v. Crowninshield, 17 U.S. (4 Wheat.) 120, 200 (1819); $c f$. El Paso v. Simmons, 379 U.S. 497, 507-08 (1965).

${ }^{107}$ See cases cited note 98 supra. For a good discussion of those cases, see B. WRIGHT, supra note 40 , at $112-19$.

${ }^{108}$ But see cases cited notes 68, 82 supra.

${ }^{109} 292$ U.S. 426 (1934).

${ }^{110}$ Id. at 433 .

111295 U.S. 56 (1935). 
Blaisdell in holding unconstitutional a statute that greatly reduced the default remedies for the security of negotiable bonds. ${ }^{12}$ After noting that the statute explicitly relied on the depression emergency, Justice Cardozo stated that "[e]ven when the public welfare is invoked as an excuse, these bounds must be respected. ... With studied indifference to the interests of the mortgagee... [the legislature has] taken from the mortgage the quality of an acceptable investment for a rational investor." 113 Justice Brandeis' majority opinion in Louisville Joint Stock Land Bank v. Radford ${ }^{114}$ supports this interpretation of Blaisdell. In striking down, under the fifth amendment, a federal farm mortgage moratorium act, the Court stated that the Blaisdell statute was sustained because it preserved "substantially the right of the mortgagee to obtain ... payment of the indebtedness." 115 When, in Kavanaugh, "it appeared that [the mortgagee's] substantive right was substantially abridged," the statute, noted Brandeis, was declared unconstitutional. ${ }^{116}$

If Blaisdell is read in light of these later cases as limiting use of the police power to situations in which substantive contract rights are not abridged substantially, ${ }^{117}$ it could be argued that the wage freeze and debt moratorium are unconstitutional. Granting the mayor the power to reduce wages of municipal employees by an average of $6 \%,{ }^{118}$ even though the municipal employees have a vested contractual right to those wages, could be considered a substantial abridgment of a substantive contract right. The same could be said about a debt moratorium that allows the city to extend the period for payment of principal and to reduce the interest rate.

Thus, if these post-Blaisdell cases are read as prohibiting "substantial" impairment of important contract rights, the legislative solutions to the New York City fiscal crisis should be held unconstitutional on that ground. An even stronger basis for distinguishing Blaisdell from the New York situation, however, is the fact that New York was a party to all the contracts impaired

112 Justice Cardozo stressed that none of the restrictions found in the legislation upheld in Blaisdell, see text accompanying note 104 supra, was present in the Kavanaugh legislation. 295 U.S. at 63.

113295 U.S. at 60.

114295 U.S. 555 (1935).

${ }^{115} \mathrm{Id}$. at 581 .

${ }^{116} \mathrm{Id}$.

${ }^{117}$ Although the facts of the cases upholding state legislation under Blaisdell, see cases cited notes 68,82 supra, do not necessarily preclude this narrower interpretation, the language of the cases evidences a broader reading of Blaisdell.

${ }^{118}$ N.Y. Times, Aug. 30, 1975, at 8, col. 1. 
by the emergency legislation. The next sections of this Comment will present the theory and case law that point to the unconstitutionality of the two laws on this basis. Then, a new constitutional scheme for emergency legislation will be proposed.

\section{Impairment of Contracts to Which the State Is A PARTY}

\section{A. Introduction}

For purposes of this Comment, it is useful to classify state interference with contract rights into four categories. First, there are situations in which the state legislation ${ }^{119}$ impairs the obligation of purely private contracts. ${ }^{120}$ Blaisdell fits into this category. Second, there are situations in which legislation affects a class of contracts, only some of which involve a government body. For example, if New York were to freeze the wages of all city employees in order to fight inflation, the city's contracts with municipal employees would be affected along with private contracts. ${ }^{121}$ Third, there are cases in which legislation affects contracts to which the governing body is a party, but in which the courts interpret the contracts to imply a reservation by the government of the power to legislate for the public welfare. These cases are characterized by the state's granting to a private party a privilege, such as a license or corporate charter, without receiving direct, reciprocal benefits in return. ${ }^{\mathbf{1 2 2}}$ In all three of the above situations, state legislation affecting contract rights will be sustained if the requirements articulated in Blaisdell are met. The fourth and final situation-the one relevant to the current inquiry-involves legislation designed to impair the government's obligations under contracts between itself and private individuals, in which the government body, as an entity, receives direct, bargained-for benefits and is subject to financial obligations that, in turn, benefit the private party to the contract. Municipal employee labor agreements and government debt ob-

119 "State legislation" will be used to refer to legislation enacted by a state or any of its political subdivisions. It is well settled that a municipal ordinance enacted pursuant to power delegated by the state is a state law within the meaning of the contract clause prohibition. See Atlantic Coast Line R.R. v. City of Goldsboro, 232 U.S. 548, 555 (1914) \& cases cited therein.

${ }^{120}$ See text accompanying notes $57-72$ supra.

121 This hypothetical is suggested by California Teachers Ass'n v. Newport Mesa Unified School Dist., 333 F. Supp. 436 (C.D. Cal. 1971); see text accompanying notes 155-6I infra.

${ }^{122}$ See text accompanying notes 54-56 supra \& 162-70 infra. 
ligations are examples of this fourth type of contract. This final classification can be subdivided further into situations in which the relevant government obligation is either financial or nonfinancial.

When contracts of the fourth type are impaired, the courts have usually held that the legislation at issue is unconstitutional, ${ }^{123}$ although the decision in Faitoute Iron E Steel Co. v. City of Asbury Park ${ }^{124}$ is a notable exception. Few of these cases, however, have noted explicitly the relevance of the fact that the government was a party to the contract at issue, much less articulated a general rule based on this distinction. Nevertheless, there are sound reasons for inferring from these cases the proposition that the Blaisdell standard of review under the contract clause is inappropriate for legislation that is designed to relieve a government body of its own contractual obligations and that has the effect of impairing the vested ${ }^{\mathbf{1 2 5}}$ rights of the private parties to the contract. This proposition is particularly compelling when, as in the case of the New York wage freeze and debt moratorium, the purpose of the legislation in question is to avoid financial obligations of the government. ${ }^{126}$ Although the Asbury Park decision at first may appear to preclude such a reading of the contract clause, a close examination of the case will reveal that it is not inconsistent with the proposition that the Blaisdell scope of review is inappropriate where the state has impaired its own financial contract obligations. In fact, Asbury Park offers a useful model for reconciling the needs of New York City with the interests of the municipal employees and noteholders and with the policies of the contract clause. Before Asbury Park is discussed further, ${ }^{127}$ however, it is necessary to examine the theory and case law supporting this Comment's reading of the contract clause.

\section{B. The Theory-Resurrecting the Contract Clause}

1. Situations in Which a Strict Standard of Review

Under the Contract Clause Is Necessary

The most important distinction between the Blaisdell line of cases $^{128}$ and the New York legislation is the role of the state as a

\footnotetext{
${ }^{123}$ See text accompanying notes 171-213 infra.

124316 U.S. 502 (1942); see text accompanying notes 83-89 supra.

${ }^{125}$ See text accompanying notes 211-13 infra.

${ }^{126}$ See text accompanying notes $132-42$ infra.

${ }^{127}$ See text accompanying notes 214-34 infra.

${ }^{128}$ See text accompanying notes 57-69 supra.
} 
party to the contract. In Blaisdell, the Court was willing to assume that if legislation is for a "legitimate purpose" and is not "arbitrary," it is a valid exercise of the police power. It is likely that the Court was willing to accept, with only a cursory examination of the substantive issues involved, the legislative judgment regarding the necessity of impairing private contracts, because the state is assumed to act impartially and in the best interests of the public. In such cases, the government can be viewed as a referee, weighing the interests of the private parties to the contract against the interests of society in general. ${ }^{129}$ Political forces that shape this decision act as a restraint on the legislature, and the result obtained through the legislative process is given great deference. ${ }^{130}$ The courts should not assume, however, that the government will act with such restraint and impartiality when its own contractual obligations are involved. The potential for the state to abuse the police power when judging its own case is great. Certainly, it is possible for the state to exercise its police power merely to accomplish what it failed to accomplish in contract bargaining or through the market place. There is little reason to believe that the state, given the power to alter its own contract

${ }^{129}$ The recent case of City of Safety Harbor v. Birchfield, 529 F.2d 1251 (5th Cir. 1976), presents an interesting variation to this class of cases. A group of Florida cities had signed an agreement that divided the surrounding unincorporated areas into zones and gave each city the right to plan municipal services and annexations within its particular zone. The Florida legislature subsequently passed legislation annexing a portion of Safety Harbor's agreed-upon service area to another city. The court upheld the legislation, stating:

Under the Florida Constitution, the power to annex unincorporated territory to established municipalities is vested in the state legislature. If municipalities were held to possess the power to enter into annexation agreements which the state legislature could not "impair," municipalities could dictate annexation patterns merely by signing such agreements and the legislature's prerogative in such matters would become meaningless. The Contracts Clause of the United States Constitution, art. 1, $\$ 10$, contemplates no such result, and the City of Safety Harbor's effort to predicate a civil rights action on a purported right derived from that clause is without merit.

Id. at 1255 (footnote omitted). This result is clearly correct even though the obligation of a municipality's contract was at issue, because, in effect, the relationship of the municipalities to the state was identical to the relationship of the state to the individual parties to the contract in Blaisdell.

${ }^{130}$ See, e.g., Home Bldg. \& Loan Ass'n v. Blaisdell, 290 U.S. 398 (1934):

"In addition to the weight to be given the determination of the legislature that an economic emergency exists which demands relief, the court must take notice of other considerations. The members of the legislature come from every community of the state and from all the walks of life. They are familiar with conditions generally in every calling, occupation, profession, and business in the state."

Id. at 422 (quoting Blaisdell v. Home Bldg. \& Loan Ass'n, 189 Minn. 422, 429, 249 N.W. 334,337 (1933)). 
obligations unilaterally, will act with more restraint than any individual who is given the opportunity to escape the terms of an onerous contract. As the New York Appellate Division has noted: "Courts should not be astute [sic] to enable a municipal corporation to disavow its just commitments or obligations, or to conduct itself respecting them in a manner violative of fair dealing, which they would not sanction were natural persons the parties involved."131

Not only is the potential for abuse of the police power greatly increased when the state is a party to the contract, but when, as in the present situation, the relevant state obligation is purely financial, ${ }^{132}$ the "public interest" is not as likely to be affected by the contract in the same sense that it was in Blaisdell. ${ }^{133}$ Thus, it is even more likely that the police power will be abused in such cases. In the cases discussed above, in which the police power was invoked successfully despite contract impairment, the contract terms directly affected the welfare of the public, either because the contract was public in nature ${ }^{134}$ or because emergency conditions rendered the terms contrary to the public interest. ${ }^{135}$ Unless impairment of such a contract were allowed, the government would be precluded from taking some step essential to the public welfare. Thus, the Court in Blaisdell spoke of "the vital interest of [the State's] people,"136 "the peace and good order of society,"137 and the "urgent public need demanding . . relief." 138

In none of those cases, however, did the government have a financial stake in the nature of the relief granted. Even if the

${ }^{131}$ Lowe v. City of New York, 240 App. Div. 484, 489, 270 N.Y.S. 216, 221 (1934), aff'd, 265 N.Y. 583, 193 N.E. 331 (1934); see Wa-Wa-Yanda, Inc. v. Dickerson, 18 App. Div. 2d 251, 258, 239 N.Y.S.2d 473, 481 (1963).

132 Note that a government contract might contain some nonfinancial conditions that would not preclude the exercise of police power. For example, if a municipal employee contract contained a provision not to "bus" students to achieve racial integration, such a provision should not prevent the state from later busing students if the legislature felt this to be in the public interest. In such a situation, however, the state itself, as an entity, has nothing to gain from the legislation, and thus deserves the presumption that the purpose of the legislation is to foster the public welfare. Moreover, the subject matter of such a provision is of unusual public importance, see notes 52-53 supra \& accompanying text, and the clause might even be considered an impermissible bargaining away of the police power, see notes 54-56 supra \& accompanying text. For a further discussion of nonfinancial contract terms, see text accompanying notes 162-70 infra.

\footnotetext{
${ }^{133}$ See text accompanying notes 61-62 supra.

${ }^{134}$ See cases cited notes 52-55 supra.

${ }^{135}$ See cases cited note 68 supra.

${ }^{136}$ Home Bldg. \& Loan Ass'n v. Blaisdell, 290 U.S. 398, 434 (1934).

${ }^{137}$ Id. at 435 .

${ }^{138}$ Id. at 440 .
} 
legislature's interest in government contracts in general is not sufficiently prejudicial to invoke the contract clause in all cases, when government contracts impose financial obligations on the state, the legislature will always have an interest in reducing the size of those financial obligations. Once "emergency" conditions arise, the state has every incentive to abuse its police powers by reducing, as much as possible, its financial obligations without regard either to the interests of the private parties to its contracts or to the equity of its action. Nonetheless, the Flushing ${ }^{139}$ and Transit Authority ${ }^{140}$ courts adopted a standard of review that gives great deference to the legislature's judgment concerning the necessary relief. The Blaisdell standard of review is inappropriate when the government is a party to the contract at issue, particularly when the government's contractual obligations are financial.

In the wage freeze dispute, the city could have argued that the real purpose of the measure was not to save money, but to use the funds withheld from its employees to promote public welfare by ensuring stability within the city and by reducing the need for more taxes. To the extent, however, that such alternative uses were for normal public welfare projects rather than for combating emergency conditions, this argument proves too much, because, under any conditions, long-term obligations such as pensions and labor contracts have an opportunity cost that restricts a city's flexibility in spending funds for other purposes. The fact that there are socially beneficial, alternative uses for these funds is no justification for allowing avoidance of contract obligations, especially when the alternative uses are not related to the particular contracts at issue. Such an argument, if accepted, could be invoked at almost any time and would render the financial obligations of government bodies meaningless. As the Supreme Court stated in Von Hoffman v. City of Quincy, ${ }_{141}$ "[a] different result would leave nothing of the contract, but an abstract right-of no practical value-and render the protection of the Constitution a shadow and a delusion."142

${ }^{139}$ Flushing Nat'l Bank v. Municipal Assistance Corp., 84 Misc. 2d 976, 379 N.Y.S.2d 978 (Sup. Ct. 1975), aff'd, 52 App. Div. 2d 84, 382 N.Y.S.2d 764 (1976), appeal docketed, No. 392, Sept. Term, 1976 (debt moratorium).

${ }^{140}$ Subway-Surface Supervisors v. Transit Auth., 85 Misc. 2d 695, 381 N.Y.S.2d 186 (Sup. Ct. 1976) (wage freeze).

14171 U.S. (4 Wall.) 535 (1867); accord, Wolff v. New Orleans, 103 U.S. 358, 369 (1881). Von Hoffman held that a state may not withdraw from a local government the powers necessary to carry out valid financial obligations.

${ }^{142} 71$ U.S. (4 Wall.) at 555. 
Moreover, it is unclear whether reducing expenditures through a wage freeze or imposing a moratorium on debt, for the purpose of freeing funds needed to finance other public programs, will serve the best interests of the public in the long run. New York responded to the fiscal crisis by passing legislation that it believed to be the best solution to the immediate crisis. It is unlikely, however, that judicial sanction of such legislation will be in the long-run interest of either New York or other municipalities throughout the nation. One of the major objectives of the contract clause was to ensure that individuals could rely confidently on contractual obligations of others. As Madison wrote, this constitutional assurance was created in order to "inspire a general prudence and industry and give a regular course to the business of society."143 If the judiciary, by exercising only cursory review, ultimately allows the legislatures to avoid their contractual obligations, public confidence in municipalities' compliance with such obligations could be severely shaken. Municipal employee unions may have no choice but to continue bargaining with municipalities, but investors do not have to invest in municipal bonds. Certainly, the added risk for investors that the legislature might declare an emergency, refuse to pay principal when due, and reduce interest payments will be reflected in higher interest rates for municipal borrowing. Many American cities are presently in unsound fiscal condition and are experiencing such great difficulties in financing debt ${ }^{144}$ that any increase in the risk of such loans could dry up the municipal bond markets. Eventually, the public would have to pay for the increasing cost of maintaining municipal debt.

The following report on a meeting of 125 large banks underscores this problem:

If the [Moratorium Act] is upheld, all issues in the state will continue to carry interest costs much higher than they otherwise would and that will mean higher tax bills. One banker estimated that the $\$ 54$ million Suffolk County sewer bond issue sold last week at a 9.77 percent interest rate cost would have carried a rate of only 6.50 percent if there had been no moratorium. If the moratorium is upheld in court, the bonds of all

${ }^{143}$ The Federalist No. 44, at 319 (B. Wright ed. 1961) (J. Madison); see Home Bldg. \& Loan Ass'n v. Blaisdell, 290 U.S. 398, 427 (1934); id. at 454-64 (dissenting opinion); B. WRIGHT, supra note 40, at 4-6, 14; text accompanying note 43 supra.

${ }^{144}$ See note 149 infra. 
financially shaky states-mainly those in the Northeast and Midwest-will be suspect, several underwriters here contended. ${ }^{145}$

The opinions of underwriters with a vested interest in the outcome of the litigation may be suspect, but others also have warned of the consequences of judicial sanction of the Moratorium Act. The following viewpoint from an opinion letter of counsel contained in a MAC bond prospectus will hardly increase investor demand for government bonds:

In the event that the constitutionality of said Moratorium Act is sustained by a court of final jurisdiction, such judicial determination could support the constitutionality of similar legislative enactments which may adversely affect certain terms and conditions of the Bonds and the Resolutions, including the payment of principal and interest thereon, and the enforceability thereof. ${ }^{146}$

As New York City Comptroller Harrison J. Goldin noted:

In the aftermath of a possible New York City default, who would predict that in the ensuing litigation, the major underlying historic security for tax-exempt obligations, full faith and credit, would not be interpreted by a court of law to mean less than for 200 years it has been assumed to mean in American public finance? And if it were to be interpreted definitively and authoritatively to mean less than it has historically been assumed to mean, I believe that in the period of chronic capital short-fall into which we are entering, tax-exempt jurisdictions, which are going to have difficulty enough obtaining credit under the best of circumstances, even at rates higher than we are experiencing today, would run the risk of being virtually unable to borrow at any price. ${ }^{147}$

Although it might be reasonable, if New York were the only city that would be affected, for the courts to allow the New York legislature to choose a present remedy knowing that it would increase its borrowing costs in the future, their recent decisions

145 N.Y. Times, Jan. 19, 1976, at 43, col. 6.

${ }^{146}$ MAC Prospectus, supra note 8, Exhibit A, at 6.

${ }^{147}$ Goldin, New York City's Financial Crisis, Princeton Alumịi WeEkly, Dec. 1, 1975, at 8, 12. 
upholding New York's policy judgment will adversely affect other states and municipalities as well. New York cannot be expected to weigh the interests of these other municipalities in considering its own legislation; therefore, the policies of the contract clause warrant greater judicial scrutiny of such legislation than the Flushing courts exercised. ${ }^{148}$

Even if courts required a finding of "emergency" conditions before the state could exercise the police power to avoid its financial obligations, many municipalities would still be able to avoid unwanted financial burdens. While no other city is in as dangerous a position as New York, the fiscal condition of a number of municipalities is sufficiently unsound to warrant an "emergency" declaration. ${ }^{149}$ Moreover, it is likely that in the fu-

${ }^{148}$ See text accompanying notes $90-96$ supra.

${ }^{149}$ Don Birmingham, of the League of California Cities, recently stated that, "Similar problems [to those of New York City], in lesser degree, exist across the nation, and many steps have been taken to help ease the burdens." InTERNational CrTy Management Association, The Municipal Yearbook 1976, at 45. He described state legislative efforts to ease municipal fiscal burdens in Arkansas, Georgia, Iowa, Louisiana, Minnesota, Missouri, Montana, Nevada, New Jersey, New Mexico, Ohio, Pennsylvania, South Dakota, and Wyoming.

In November, 1975, Newsweek compiled a list of ten cities expected to encounter debt servicing difficulties in the months ahead. The list, based in part on the bond rating of those cities as reported by Moody's Investors Service, indicates the following bond ratings for the ten cities: Boston-A; Buffalo-Baa; Cleveland-A; Detroit-Baa; Hoboken- $B a$; Jersey City-Baa 1 ; Newark-Baa; Philadelphia- $A$; Wilmington- $A 1$; and Yonkers-Baa. NewsWEEK, Nov. 10, 1975, at 25.

Moody's Investors Service reports on the general obligation bond rating of most American cities on a scale from $\mathrm{Aaa}$ (a gilt-edged security) to $C$ (an extremely poor risk). Of major cities, New York presently has the lowest bond rating reported by Moody's; it is classified as Caa, indicating a poor risk. Other than the cities listed above, those having a rating of $A$ (an investment with some favorable attributes) include Albany, Gary, and St. Louis. Erie has a rating of Baa 1, denoting its bonds as better medium grade investments. Camden, Las Vegas, and Scranton have Baa ratings, indicating a medium grade investment. The $B a$ rating received by Hoboken is indicative of a speculative investment risk. Moody's INvestors Service, INC., MOODY's MuNICIPAL and Government Manual (1976). Nine months after the Newsweek listing, four of the ten cities had even lower ratings. Boston and Philadelphia had fallen from $A$ to $B a a$, and Buffalo and Yonkers had dropped from Baa to Ba.Id. (Supp. Aug., 1976).

It has been suggested that a municipality that is presently experiencing a decline in population may expect to encounter financial difficulties at some time in the future. This is particularly true of older cities that are losing young, middle-income households to the suburbs, while suffering from increased operational costs attributable to the age of the cities' physical plant, to increased welfare and social service expenditures, and to the necessity of negotiating with strong municipal employee unions. Among the major cities that have experienced a decline in population since 1960 are Baltimore, Boston, Buffalo, Chicago, Cincinnati, Cleveland, Detroit, Milwaukee, New Orleans, Philadelphia, Pittsburgh, St. Louis, San Francisco, and Seattle. Demkovich \& Peirce, Urban Report, 7 Nat. J. Rep. 1540, 1542 (1975); see C. Schultze, E. Fried, A. Rivlin \& N. Teeters, Setting National Priorities: The 1972 Budget 142-43 (1972) [hereinafter cited as Schultze]; U.S. Advisory Comm'n on Intergovernmental Relations, City 
ture an increasing number of municipalities will experience financial crises, especially during periods of recession or high inflation. ${ }^{150}$ Thus, one federal study has noted that "fiscal and political tightness in the financial affairs of cities . . . makes them increasingly susceptible to financial emergencies." 151 A Brookings Institution report calling for revenue sharing as a long-term solution to the urban crisis has predicted that "in areas with large low-income populations and in congested and deteriorating central cities, the [fiscal] situation is desperate and likely to get worse." ${ }^{152}$ To the extent that these predictions are accurate, one consequence of upholding legislation that impairs a state's contractual obligations upon a declaration of emergency would be to ensure that almost any attempt by a municipality to avoid its financial contract obligations would succeed. ${ }^{153}$ The contract clause should not be interpreted so that the validity of contracts made with the state depends solely on the state's willingness to abide by its bargained-for obligations.

Finally, even if a valid declaration of emergency justifies the exercise of the police power when the state is a party to a mutually beneficial contract, it can be argued that no government's fiscal crisis should constitute such an "emergency." Surely New York City officials knew about the city's precarious fiscal condition long before any of the present labor agreements was signed

Financial Emergencies 4, 36-57 (1973) [hereinafter cited as City Financial EMERGENCIES].

${ }^{150}$ While it is beyond the scope of this Comment to analyze the causes of urban fiscal problems, any list of contributing factors should include the increasing demand for city services, the labor-intensive nature of city services (which prevents productivity from keeping pace with inflation-induced cost increases), stronger unions, and the demise of the "economically balanced" city (caused by the flight of the middle and upper classes to the suburbs). None of these factors appears to be short-term, and it is therefore likely that the urban financial situation will continue to worsen in the foreseeable future.

151 City Financial EMergencies, supra note 149, at 56.

152 Schultze, supra note 149 , at 143 . But see E. Fried, A. Rivlin, C. Schultze \& N. Teeters, Setting National Prioriries: The 1974 Budget 269-73 (1974) (authors conclude that, "[i]n retrospect, the fears of spreading municipal bankruptcy, chronic state budget difficulties, and continuing program cutbacks were exaggerated." Id. 269).

${ }^{153}$ The courts could attempt to examine closely all such declarations of fiscal emergency, but such an approach would pose serious problems. It is unlikely that courts are competent to judge the relative severity of fiscal crises. In any event, such a task would prove fruitless to the extent that the relevant information would be under the exclusive control of the municipality itself. In addition, it is unlikely that a court would question a legislative judgment that an emergency exists. Rather, its inquiry would probably be limited to whether the particular declared emergency justifies contract impairment-the inquiry at issue here. See W.B. Worthen Co. v. Kavanaugh, 295 U.S. 56, 63 (1935); W.B. Worthen Co. v. Thomas, 292 U.S. 426, 432-34 (1934); Home Bldg. \& Loan Ass'n v. Blaisdell, 290 U.S. 398, 421-22, 444 (1934). 
or any short-term debt was issued. ${ }^{154}$ Thus the city cannot claim that totally unforeseen circumstances arose, subsequent to the signing of municipal labor contracts or the issuing of notes, that required the exercise of the police power. Rather, the contracts were signed and the notes issued by the city with the knowledge of the possible consequences. When a city assumes such a risk, the courts at the very least should not allow it to abrogate obligations unilaterally solely upon a declaration that the risk has materialized. Instead, the courts in such cases should subject the legislation to a much stricter scope of review than that used in Flushing.

\section{Situations in Which the Minimal Blaisdell Standard of Review Is Appropriate}

\section{a. A State Obligation as Part of a Larger Class of Contracts}

In some situations a state's contractual obligations should not stand in the way of the government's exercise of the police power. ${ }^{155}$ When the government's contractual obligation constitutes a part of a larger class of contracts that are affected by a regulation in the public interest, the arguments advanced above $^{156}$ lose much of their force. Thus, in California Teachers

${ }^{154}$ A cursory review of public statements by interested individuals demonstrates an awareness of the city's situation as early as 1968, when "Abraham D. Beame, former City Controller, accused the Lindsay administration ... of bringing on a fiscal crisis 'that means just one thing-more taxes for next year.' " N.Y. Times, Jan. 5, 1968, at 46, col. 1 . See Metz, Market Place: What Portends Troubled Cities?, id., Mar. 24, 1971, at 58, col. 3 (quoting view of economist Alan Greenspan that while there are adequate funds buried in the city's budget to carry it through several crises, eventually the city will be forced to go on a cash basis, when "crises will mean cuts in vital services"); Reeves, The War Over How to Pay the Urban Bill, id., Jan. 3, 1971, § 4, at 1, col. 1 (Mayor Lindsay, in rejecting a request for welfare funds, states that the rising cost of welfare "has put the city in a position where it either has to risk bankruptcy and elimination of basic essential services, or adopt the kind of drastic action I have announced today."); id., Mar. 16, 1972, at 46, col. 4 (letter to editor expresses alarm at $48 \%$ increase in city debt service); id., Mar. 1 , 1972, at 38, col. I (budgetary announcement "foreshadows the gravest kind of fiscal problem for the city"); id., Apr. 20, 1971, at 42, col. 1 (editorial warns of "acute fiscal crisis" and "emergency" created by a shortage of funds); id., Jan. 23, 1971, at 1, col. 7 (Mayor Lindsay testifies to a congressional committee that New York City's budget gap in next fiscal year might approach $\$ 1$ billion); id., Mar. 1, 1969, at 19, col. 2 (report to the City Planning Commission notes that the city will require $\$ 18$ billion over the next decade-four times what it can expect to receive-to meet its housing, urban renewal, school construction, and recreational needs); id., Feb. 2, 1969, § 1, at 58, col. 2 (City Controller Mario A. Procaccino criticizes the Lindsay administration's fiscal policies and blames the mayor "for the fact that our credit rating is down").

${ }^{155}$ See text accompanying notes 121-22 supra.

${ }^{156}$ See text accompanying notes $119-54$ supra. 
Association v. Newport Mesa Unified School District, ${ }^{157}$ a district court rejected a union's constitutional attack on the wage-price freeze imposed by the school district in accordance with the requirements of the Economic Stabilization Act. ${ }^{158}$ The court stated that, even assuming that the contract clause applies to the federal government through the due process clause of the fifth amendment, the wage controls constituted a proper exercise of the police power under Blaisdell. ${ }^{159}$ Unlike the New York law at issue here, however, the federal wage controls were designed to affect all labor contracts; any effect on contracts between unions and government entities was only incidental. It is unlikely that a government will pass general legislation of such broad scope as a pretense for impairing its own contractual obligations. Thus, the potential for abuse that exists when only government contracts are affected by state legislation is greatly reduced when the law is universal in scope. For the same reasons that private contracts between individuals should not interfere with the reasonable exercise of the state's police power, ${ }^{160}$ the fact that the government is a party to some ${ }^{161}$ labor contracts should not invalidate otherwise valid legislation that impairs labor contracts in general.

\section{b. The Charter-License Cases}

There is one other situation in which the fact that the state is a party to a contract should not require the use of the strict standard of review proposed in this Comment. When the state grants a privilege ${ }^{162}$ such as a twenty-five-year lottery license, ${ }^{163}$ a franchise to carry fertilizer, ${ }^{164}$ or a corporate charter to manufacture beer, ${ }^{165}$ the courts will infer a reservation by the state of its police power. One can distinguish these cases from the New York wage freeze and debt moratorium by focusing both on the nonfinancial purpose of the impairments ${ }^{166}$ and on the nature of

157333 F. Supp. 436 (C.D. Cal. 1971).

${ }^{158}$ Act of Aug. 15, 1970, Pub. L. No. 91-379, tit. II, 84 Stat. 799, as amended, Pub. L. No. $92-15, \S 3,85$ Stat. 38 (197I).

159333 F. Supp. at 444.

${ }^{160}$ See text accompanying notes $128-30$ supra.

161 Of course, if a very large proportion of the labor contracts affected by the legislation were government contracts, there might be cause to invoke the higher level of scrutiny proposed in this Comment.

${ }^{162}$ See text accompanying notes 54-56, 122 supra.

${ }^{163}$ Stone v. Mississippi, 101 U.S. 814 (1880); see text accompanying notes 54-56 supra.

${ }^{164}$ Fertilizing Co. v. Hyde Park, 97 U.S. 659 (1878); see note 55 supra.

165 Beer Co. v. Massachusetts, 97 U.S. 25 (1878).

${ }^{166}$ In Stone and Beer Co., the legislation was justified as necessary for the public 
the government's role as a party to the contract. In cases in which the government extends a privilege without receiving any direct benefit in return, ${ }^{\mathbf{1 6 7}}$ it is reasonable to infer that the private party accepts the privilege subject to the state's potential exercise of the police power. The recipient is in no position to refuse conditions that the government places on its granting of a privilege, as long as those conditions are consistent with normal constitutional restraints on government action.

It would be unrealistic, however, to infer, as a condition to a contract between bargaining adversaries that contains reciprocal obligations and benefits, that one party (the state) has reserved the power to void its obligations. The municipal unions in the New York wage freeze situation agreed to provide certain services in return for stipulated wages and benefits. To suggest that they accepted those terms subject to the state's power to modif $y^{r}$ them if the contract should become onerous or unprofitable is to state that no mutually binding contract existed in the first place. Furthermore, this reserved-power proposition is even less tenable in the debt moratorium case. Each of the city's note certificates stated "that for the punctual payment of the principal and interest of this Revenue Anticipation Note, as the same become due and payable, the faith and credit of the City are hereby irrevocably pledged."168 In addition, the Notice of Sale of the City that invited bidding on these issues stated:

Notes will be general obligations of the City, all the taxable real property within which will be subject to the levy of ad valorem taxes to pay said Notes and the interest thereon, without limitations as to rate or amount. Payment of debt service shall be the first lien on all the City's revenues. The State Constitution requires the City to pledge its faith and credit for the payment of the principal of the Notes and the interest thereon. ${ }^{169}$

Thus, the courts should not apply a doctrine taken from cases in which the government extended a privilege subject to

morals, 101 U.S. at $818 ; 97$ U.S. at 32 ; in Fertilizing Co., the legislation was found to be required in order to protect the public health, 97 U.S. at 664 .

${ }^{167}$ The government might benefit indirectly through taxes or licensing fees, and the public may benefit from the opportunity to purchase services and goods, but these benefits are at most incidental to the contract.

${ }_{168}$ Brief for Appellant at 8, Flushing Nat'l Bank v. Municipal Assistance Corp., 52 App. Div. 2d 84, 382 N.Y.S.2d 764 (1976), appeal docketed, No. 392, Sept. Term, 1976 (emphasis supplied).

${ }^{169} \mathrm{Id}$. Similar language is found in an opinion of the counsel for the city's underwriters, which accompanied the delivery of the note certificates to the purchaser.Id. 
the exercise of police power to a situation in which, by contrast, the government has provided benefits in return for equivalent, bargained-for benefits, and in which the reservation of the police power would have been unacceptable to the private party in the first instance. Moreover, when the government has not incurred any obligations from a contract other than the obligation to honor the privilege granted, it is unlikely that the governmental entity will have any interest in impairing the contract for reasons other than to promote the public welfare. ${ }^{170}$ Consequently, there is greater potential for abuse of the police power in the charterlicense situation than in situations in which the government has incurred financial obligations that may later prove burdensome. The police power doctrine should not be extended to situations in which the state is neither disinterested nor impartial, or in which the state's financial interests are at stake. If the constitutional prohibition against impairment of contracts is to protect individuals from governmental abuse of power, the situations presented by the wage freeze and debt moratorium clearly warrant its application.

\section{The Case Law}

While an examination of the case law in which the state is a party to a mutually beneficial contract is not dispositive, the cases lend some support to the proposition that a state may not unilaterally impair its bargained-for contractual obligations. The Supreme Court has often invoked the contract clause to prevent states from repudiating their financiai obligations. ${ }^{171}$ For example, the Court has held that a state may not withdraw from a local government the powers it needs to honor its valid financial obligations. ${ }^{172}$ The Court has also applied this principle to

${ }^{170}$ In some cases in which the state has granted a privilege, there may be a financial incentive for the state to revoke the privilege. For example, when a state has granted retail liquor-sales licenses, the state may gain financially by revoking the licenses and operating state liquor stores itself. In such a case, the contract might not be considered to come within the "charter-license" exception, but instead might be treated as a government contract involving financial obligations. It is submitted, however, that the motives for revoking private licensing agreements are more often to keep "undesirable" persons out of the businesses than to fill the state's coffers.

${ }_{171}$ See Louisiana $e x$ rel. Hubert v. Mayor \& Council of New Orleans, 215 U.S. 170 (1909); Louisiana v. Pilsbury, 105 U.S. 278 (1882); Wolff v. New Orleans, 103 U.S. 358, 365 (1881); Murray v. Charleston, 96 U.S. 432 (1878); Board of Liquidation v. McComb, 92 U.S. 531 (1876); Von Hoffman v. City of Quincy, 71 U.S. (4 Wall.) 535 (1867); Rorick v. Board of Comm'rs, 57 F.2d 1048 (N.D. Fla. 1932); B. WRIGHT, supra note 40, at 224-35. Note, however, that all of these cases occurred before Blaisdell.

${ }^{172}$ Von Hoffman v. City of Quincy, 71 U.S. (4 Wall.) 535 (1867); see Louisiana ex rel. Nelson v. Police Jury, 111 U.S. 716 (1884); Louisiana v. Pilsbury, 105 U.S. 278 (1882); Wolff v. New Orleans, 103 U.S. 358 (1881). 
the case of a person performing services for a municipality. ${ }^{\mathbf{1 7 3}}$ Likewise,

where a municipal corporation is authorized to contract, and to exercise the power of local taxation to meet its contractual engagements, this power must continue until the contracts are satisfied, and ... it is an impairment of an obligation of the contract to destroy or lessen the means by which it can be enforced. ${ }^{174}$

The Court has repeatedly voided states' attempts to modify their own debt obligations. In Murray $v$. Charleston, ${ }^{175}$ the Court declared unconstitutional a tax levied upon municipal bonds, when the statute provided that $2 \%$ of the stipulated $6 \%$ interest would be retained in payment of the tax. The Court said that the state had, in effect, converted its $6 \%$ interest obligation into a $4 \%$ debt. While recognizing that all contracts are made with reference to the taxing power residing in the state, the Court refused to infer in the loan contract a reservation of the debtor municipality's right to raise contributions from the money owed to the lender. To infer such a reservation would mean that

the contract (in the language of Alexander Hamilton) would "involve two contradictory things: an obligation to do, and a right not to do; an obligation to pay a certain sum, and a right to retain it in the shape of a tax. . . ." A promise to pay, with a reserved right to deny or change the effect of the promise, is an absurdity. ${ }^{176}$

The Court, again quoting Hamilton, then articulated the following rule for taxing money that is received under a contract with the government:

"It must first be reduced into possession, and then it will become subject, in common with other similar property, to the right of the government to raise contributions upon it. It may be said that the government may fulfil this principle by paying the interest with one hand, and taking back the amount of the tax with the other. But to this the answer is, that, to comply truly with the rule, the tax must be upon all the money of the community,

${ }^{173}$ Fisk v. Jefferson Police Jury, 116 U.S. 131 (1885).

174 Louisiana ex rel. Hubert v. Mayor \& Council of New Orleans, 215 U.S. 170, 175-76 (1909); see Wolff v. New Orleans, 103 U.S. 358, 365 (1881).

17596 U.S. 432 (1878).

${ }^{176} I d$. at 445 (emphasis supplied). 
not upon the particular portion of it which is paid to the public creditors, and it ought besides to be so regulated as not to include a lien of the tax upon the fund. The creditor should be no otherwise acted upon than as every other possessor of money; and consequently the money he receives from the public can then only be a fit subject of taxation when it is entirely separated" (from the contract), "and thrown undistinguished into the common mass." 3 Hamilton, Works, 514 et seq. ${ }^{177}$

Otherwise, a state's contracts would not "have the same meaning as that of similar contracts between private persons." 178 As Hamilton explained in a communciation to the Senate contained in a later portion of his collected writings:

When a government enters into contract with an individual, it deposes as to the matter of the contract, its constitutional authority, and exchanges the character of legislator for that of a moral agent, with the same rights and obligations as an individual. Its promises may be justly considered as excepted out of its power to legislate, unless in aid of them. It is, in theory, impossible to reconcile the two ideas of a promise which obliges with a power to make a law which can vary the effect of it. ${ }^{179}$

The debt modification cases, such as Murray, lend support to the proposition that New York City may not unilaterally modify its debt obligations or the financial aspects of its contractual labor agreements. All of these situations are characterized by a reduction of vested, but future, contractual benefits-interest payments in Murray and in the debt moratorium situation, and wages in the wage freeze situation. Moreover, in all these situations the government is a party to contracts with bargained-for mutual obligations and benefits, and the purpose of the contract impairments is financial. The wage freeze, which affects only municipal labor contracts, can be analogized to a tax solely on those contracts. Although New York could exercise its police power to tax wages in general, the language from Murray quoted above ${ }^{180}$ would seem to preclude the city's singling out its own contracts for special treatment.

\footnotetext{
${ }^{177} I d$. at 446 (emphasis supplied).

${ }^{178} \mathrm{Id}$. at 445.

1793 A. Hamilton, The Works of Alexander Hamilton 518-19 (1851) (emphasis

${ }_{180}$ Text accompanying notes $175-78$ supra.
} in original). 
Of course, Murray and the other debt modification cases ${ }^{181}$ were decided prior to Blaisdell, and the police power doctrine has expanded significantly since the Murray decision. Moreover, as the discussion of Faitoute Iron E Steel Co. v. City of Asbury Park ${ }^{182}$ will demonstrate, an absolute prohibition on the state's exercise of police powers may not be wise. Nonetheless, the policies of Murray support the proposition that the limited scope of judicial review established in Blaisdell ${ }^{\mathbf{1 8 3}}$ and applied in Flushing National Bank v. Municipal Assistance Corp. ${ }^{184}$ is inappropriate in the wage freeze and debt moratorium situations.

Even if the holding in Murray is relevant to the New York situation, the emergency declarations in the New York ordinances might distinguish the present situation from that in the Murray line of cases, because in none of the early debt repudiation cases was it argued that an "emergency" required the contract impairment. Even if an emergency declaration is justified in this situation, ${ }^{185}$ however, the holding in Murray indicates that states, upon entering into this type of contract, have no powers beyond those of ordinary contracting parties: "They come down to the level of ordinary individuals. Their contracts have the same meaning as that of similar contracts between private persons." ${ }^{186}$ Certainly, financial emergency or the inability to pay a contract obligation, even to the extent of insolvency, is no justification for the repudiation of a private contract. ${ }^{187}$

In Lynch $v$. United States, ${ }^{188}$ decided a short time after Blaisdell, Justice Brandeis' majority opinion suggested that the need for government economizing cannot justify repudiation of contract obligations. The case involved an attempt by Congress during the Depression to cancel war risk life insurance policies issued to individuals during World War I. The Court, finding that the insurance policies constituted contracts with the United States, held that the due process clause of the fifth amendment prohibited repudiation of the contract obligations because the

181 See notes 171-74 supra.

182316 U.S. 502 (1942); text accompanying notes 217-24 infra.

${ }^{183}$ See text accompanying notes 57-65 supra.

${ }^{184} 84$ Misc. 2d 976, 379 N.Y.S.2d 978 (Sup. Ct. 1975), aff'd, 52 App. Div. 2d 84, 382 N.Y.S.2d 764 (1976), appeal docketed, No. 392, Sept. Term, 1976; see text accompanying notes $90-96$ supra.

${ }^{185}$ See text accompanying notes $149-54$ supra.

18696 U.S. at 445.

187407 East 61 St. Garage, Inc. v. Savoy Fifth Ave. Corp., 23 N.Y.2d 275, 244 N.E.2d 37, 296 N.Y.S.2d 338 (1968); see Central Trust Co. v. Chicago Auditorium Ass'n, 240 U.S. 581 (1916); RESTATEMENT OF CONTRACTS $\$ \$ 454,467$ (1932).

${ }^{188} 292$ U.S. 571 (1934). 
legislation did not come within the fairly broad scope of the federal police power. ${ }^{189}$ In fact, the Court, while noting the fiscal problems of the government caused by the Depression, stated that the title of the legislation, an "Act to maintain the credit of the United States," itself countered any suggestion that the police power could authorize such action:

Punctilious fulfillment of contractual obligations is essential to the maintenance of the credit of public as well as private debtors. No doubt there was in March, 1933, great need of economy. In the administration of all government business economy had become urgent because of lessened revenues and the heavy obligations to be issued in the hope of relieving widespread distress. Congress was free to reduce gratuities deemed excessive. But Congress was without power to reduce expenditures by abrogating contractual obligations of the United States. To abrogate contracts, in the attempt to lessen government expenditure, would be not the practice of economy, but an act of repudiation. ${ }^{190}$

${ }^{189} I d$. at 579.

${ }^{190} I d$. at 580 (emphasis supplied). Compare Perry v. United States, 294 U.S. 330 (1935), with Norman v. Baltimore \& O.R.R., 294 U.S. 240 (1935). In Norman, the Court, per Chief Justice Hughes, held constitutional a congressional resolution retroactively altering "gold value" clauses in contracts between private parties. Yet in Perry, a companion case whose opinion was also written by Chief Justice Hughes, the Court reached the opposite result on the issue of the federal government's debt obligations, although it ultimately held against the plaintiff on the issue of damages. Speaking for himself and three other members of the Court, Chief Justice Hughes noted the relevance of the government's status as a party to the contract at issue:

There is a clear distinction between the power of the Congress to control or interdict the contracts of private parties when they interfere with the exercise of its constitutional authority, and the power of the Congress to alter or repudiate the substance of its own engagements when it has borrowed money under the authority which the Constitution confers.

294 U.S. at 350-51. Perry did not involve an emergency situation, and, because federal legislation was at issue, the contract clause was not applicable. The principle, however, that government obligations must be treated differently by the courts than private obligations is still relevant here. The four dissenters in both Perry and Norman agreed with this aspect of the Perry opinion, noting:

Can the Government, obliged as though a private person to observe the terms of its contracts, destroy them by legislative changes in the currency and by statutes forbidding one to hold the thing which it has agreed to deliver? If an individual should undertake to annul or lessen his obligation by secreting or manipulating his assets with the intent to place them beyond the reach of creditors, the attempt would be denounced as fraudulent, wholly ineffective.

....

Loss of reputation for honorable dealing will bring us unending humiliation; the impending legal and moral chaos is appalling.

294 U.S. at 380-81 (dissenting opinion). 
It appears from this language that conflicting demands for government funds, even if the funds are urgently needed to relieve "widespread distress," will not justify exercise of the police power. ${ }^{191}$

In a slightly different context, the courts have recognized the danger of allowing states to abrogate unilaterally contracts that they have entered into in their proprietary capacity. Thus in McGinn v. State Board of Harbor Commissioners, ${ }^{192}$ in which the state as owner of tidelands had sold property by reference to a map delineating public streets, the court held that the state could not revoke the dedication of a portion of a street, because to do so would impair the obligation of a contract entered into in its proprietary capacity. Likewise, in Wa-Wa-Yanda, Inc. $v$. Dickerson, ${ }^{193}$ a New York court held that where a town had leased land to a corporation for purposes of running a yacht basin and hotel, absent a finding that an emergency existed, the Constitution barred application of a zoning amendment prohibiting the sale of gasoline. The court reasoned that because the municipality had leased the premises to petitioners in its proprietary capacity, it could not, in its governmental capacity, alter the terms of the lease by a zoning enactment: "[A] contract concerning proprietary rights ... made by a municipality . . . is within the constitutional protection, and the police power cannot be invoked to abrogate or impair it." 194 Although these cases failed to articulate a clear rationale for this rule, the Dickerson court relied on the fact that "the municipality seeks escape from the obligation of [its] contract"195 in a manner that the courts "would not sanction were natural persons the parties involved."196 Though the

${ }^{191}$ See text accompanying notes 141-42 supra. Because Lynch involved federal legislation, the contract clause was not applicable and the Court nominally proceeded on fifth amendment due process grounds. The reasoning of the Court, however, should apply equally to a state contract under the contract clause. See also Louisiana v. Pilsbury, 105 U.S. 278 (1882); Wolff v. New Orleans, 103 U.S. 358 (1881). In Pilsbury, the Court declared unconstitutional a state statute repealing legislation in effect at the time New Orleans bonds were issued that authorized the levying of a special tax for payment of the bonds. Legislative findings that the city's tax base had so eroded that it would be "impossible" to pay the total debt and that further taxes would lead to "bankruptcy" did not save the statute. 105 U.S. at 298.

192113 Cal. App. 695, 299 P. 100 (1931).

19318 App. Div. 2d 251, 239 N.Y.S.2d 473 (1963).

${ }^{194} \mathrm{Id}$. at 256-57, 239 N.Y.S.2d at 479 (alternative holding) (quoting 16 C.J.S. Constitutional Law $\S 309$ (1956). But see El Paso v. Simmons, 379 U.S. 497 (1965), discussed in text accompanying notes 201-10 infra.

${ }^{195} 18$ App. Div. 2d at 256, 239 N.Y.S.2d at 478 (emphasis supplied).

${ }^{196}$ Id. at 258, 239 N.Y.S.2d at 481 (quoting Lowe v. City of New York, 240 App. Div. $484,489,270$ N.Y.S. 216, 221, aff'd, 265 N.Y. 583, 193 N.E. 331 (1934)). 
constitutionality of the New York wage freeze and debt moratorium should not turn on whether the obligations were undertaken by the city in its proprietary or governmental capacity, ${ }^{197}$ the court in Dickerson appeared to react to the same kinds of considerations as those discussed above in the context of the New York wage freeze. ${ }^{198}$

On the other hand, New York is not without case law supporting the application of Blaisdell to a state's own contracts. Besides Faitoute Iron ES Steel Co. v. City of Asbury Park, ${ }^{199}$ which will be discussed more fully below, ${ }^{200}$ the city can point to the Supreme Court's opinion in El Paso v. Simmons. ${ }^{201}$ In that case, Texas had authorized the State Land Board to sell public land under long-term contracts for the benefit of the state's school fund. The contracts provided that if a parcel of land were forfeited to the state for nonpayment of interest, the purchaser could have his claim reinstated by paying all interest due, provided that no rights of third parties had intervened. In 1941, to prevent individuals from exercising, for a nominal interest payment, reinstatement rights to land that had greatly appreciated in value, Texas passed legislation providing that the right to reinstate lands forfeited thereafter must be exercised within five years of the forfeiture. The Supreme Court, while recognizing that the statute might affect the value of the state's obligations, relied on Blaisdell in upholding the constitutionality of the provision under the contract clause.

Although Simmons involved a public contract and much of the opinion relied on Blaisdell, the Texas scenario differed materially from the New York wage freeze and debt moratorium situations. For example, in rejecting the applicability of the contract clause, the Court stated:

We note at the outset that the promise of reinstatement, whether deemed remedial or substantive, was not the central undertaking of the seller nor the primary consideration for the buyer's undertaking. ... We do not believe that it can seriously be contended that

${ }^{197}$ Probably because the proprietary-governmental distinction is somewhat artificial, the courts have not analyzed labor contracts within this framework. One Pennsylvania court that addressed the issue concluded, however, that a municipality exercises its proprietary functions when it signs labor contracts. District Council No. 33, AFSCME v.

Philadelphia, 83 Pa. D. \& C. 537, 558 (C.P. 1952).

${ }^{198}$ See text accompanying notes 119-70 supra.

199316 U.S. 502 (1942); see text accompanying notes 83-89 supra.

${ }^{200}$ Text accompanying notes 215-34 infra.

201379 U.S. 497 (1965). 
the buyer was substantially induced to enter into these contracts on the basis of a defeasible right to reinstatement in case of his failure to perform, or that he interpreted that right to be of everlasting effect. ${ }^{202}$

In contrast, the wage increases in the municipal labor contracts were certainly a primary consideration for entering into the contracts-without the wage increases, it is extremely unlikely that the unions would have ratified the agreements. A similar argument undoubtedly holds for the maturity date and interest rates on the city notes. Moreover, the Court in Simmons concluded by stating that "[l]aws which restrict a party to those gains reasonably to be expected from the contract are not subject to attack under the Contract Clause, notwithstanding that they technically alter an obligation of a contract."203 It cannot be said that the wage freeze merely restricted the unions to gains reasonably to be expected from the contract; the freeze went to the heart of the labor contract's most important provision. Nor can it reasonably be contended that the interest rate and maturity dates on the notes were not central to the noteholders' bargains.

It should be noted that a recent Eighth Circuit case, Minnesota Gas Co. v. Public Service Commission, ${ }^{204}$ cited Simmons for the proposition that all contracts, private and public, are subject to the police power as defined in Blaisdell. ${ }^{205}$ In view of the fact that the Simmons Court initially discussed Blaisdell at great length, this is not an unfair reading. To the extent that two readings of Simmons are plausible, however, the shortcomings of that opinion warrant that it be construed narrowly. The Court did not even mention, much less analyze, the relevance of the fact that the state was a party to the land sale contracts. ${ }^{206}$ Thus, even if Simmons was correct on its facts, ${ }^{207}$ a de novo analysis of the important legal issues not considred in Simmons is warranted in determining whether the contract clause should be read strictly when the state is a party to the contract at issue.

The Minnesota Gas Co. case is particularly relevant here be-

${ }^{202}$ Id. at 514 (emphasis supplied) (citations omitted).

${ }^{203} \mathrm{Id}$. at 515 (emphasis supplied).

${ }^{20.4} 523$ F.2d 581 (8th Cir. 1975), cert. denied, 96 S. Ct. 1114 (1976).

$205 I d$. at 585.

${ }^{206}$ See text accompanying notes $119-70$ supra.

${ }^{207}$ For a discussion of these facts, see text accompanying notes 202-03 supra. The Court also noted that the legislation was necessary to eliminate massive litigation over titles, to maintain stability in land sales, and to assure effective utilization of property. 
cause the court, in dicta, issued a broad pronouncement to the effect that governmental and private contracts should be treated the same under the contract clause. That language should not support New York City's actions, however, because of distinguishing features present in Minnesota Gas Co. The case involved state legislation authorizing state regulation of utility rates regardless of the effect on franchise utility contracts with the City of Minneapolis. In upholding the legislation, the Eighth Circuit relied on a previously enacted state statute permanently reserving to the state the power to fix public utility rates. ${ }^{208}$ Because the statute was in effect at the time the contract was signed, it became part of the contract. Thus, the case is analogous to the old charter and license cases, ${ }^{209}$ except that in the charter-license situation the reserved police power was supplied by judicial implication, whereas in the Minnesota Gas Co. situation the power was explicitly supplied by a statute. After using this limited rationale to uphold the statute, the court went on to cite Simmons for the broad proposition that the contract clause applies in the same way to private contracts as to public ones. ${ }^{210}$

Security Unit Employees, Council 82, AFSCME v. Rockefeller ${ }^{211}$ also provides some support for the constitutionality of the wage freeze. There, the court held that a statute removing retirement benefits from the scope of legally negotiable terms and conditions of employment was constitutional, despite the presence in the collective bargaining agreement of a clause requiring that negotiations on retirement benefits be reopened at the union's request. The court relied on Blaisdell and pointed out that retirement benefits were becoming a great burden on the public budget. ${ }^{212}$ Because public employee labor contracts were at issue and because the court applied the police power to relieve the state of a fiscal burden, this case presents facts very similar to those in the New York wage freeze situation. The court in Security Unit Employees, however, did point out that "the legislation in question does not attempt to vitiate any employee benefits which have become vested. . . . If the legislation did impair existing benefits, a different result may have been indicated." 13 Thus, whereas the legislation in Security Unit Employees impaired only the right

${ }^{208} 523$ F.2d at 584 .

${ }^{209}$ For a discussion of these cases, see notes $54-56,162-70$ supra \& accompanying text.

${ }^{210} 523$ F.2d at 585 .

21176 Misc. 2d 435, 351 N.Y.S.2d 348 (Sup. Ct. 1974).

${ }^{212}$ Id. at $438 \&$ n.l', 351 N.Y.S.2d at $352 \&$ n.1.

${ }^{213} I d$. at $438-39,351$ N.Y.S.2d at 353 (emphasis supplied) (citations omitted). 
to bargain about pensions, the New York wage freeze legislation gave the mayor the power to impair actual, vested contractual rights to wage increases. Therefore, Security Unit Employees cannot be seen as dispositive authority for New York City's position in the current situation.

IV. Asbury Park, the New York Fiscal Crisis, and a New Constitutional Framework

It has been demonstrated that contract clause theory and policies support, and that the case law may well support, the proposition that contract impairments, when the state is a party to the contract, should be subject to stricter constitutional scrutiny than is normally afforded under Blaisdell. ${ }^{214}$ Therefore, a new constitutional framework must be proposed. Under the proposed analysis, neither the New York wage freeze nor debt moratorium could pass constitutional muster. The proposed framework would allow New York and other cities to deal with their fiscal problems and at the same time would ensure that the interests of the private contracting parties are adequately protected. Before this framework is articulated, however, it will be useful to examine further a case that may shed considerable light on the issues involved here and that, despite its apparent support for the constitutionality of New York's present debt moratorium, may instead point the way to a new, and constitutionally more satisfactory, solution to some of New York's fiscal problems.

\section{A. Asbury Park}

The language quoted above ${ }^{215}$ from Faitoute Iron $\xi$ Steel Co. v. City of Asbury Park, ${ }^{216}$ which seemingly supports the constitutionality of New York's Moratorium Act, must be reexamined in light of the legislation at issue in that case. Rather than mandate an explicit plan, the New Jersey legislature authorized the submission to the state supreme court of a plan of adjustment or composition on behalf of the creditors who alleged that a municipality was unable to pay its debts in full. ${ }^{217}$ To be adopted, however, the plan had to be approved by $85 \%$ of the creditors, by the municipality, and by the state's Municipal Finance Com-

\footnotetext{
${ }^{214}$ See text accompanying notes 119-213 supra.

215 Text accompanying notes 84-89 supra.

216316 U.S. 502 (1942).

${ }^{217} \mathrm{Id}$. at 504.
} 
mission. Any plan that is negotiated under the requirement that holders of $85 \%$ of the outstanding debt must voluntarily approve it will certainly serve the financial interests of the creditors. The arguments advanced above ${ }^{218}$ for rejecting a legislature's unilateral judgements regarding modifications of its own debt obligations should not apply in a situation in which the legislature merely authorizes a municipality and its creditors to work out a mutually agreeable solution. Indeed, New Jersey did not unilaterally alter its own contract obligations, the interests of the creditors were represented because their consent was required, and, most importantly, future bondholders could purchase bonds with the assurance that the municipality's obligations could be modified only by consent of the vast majority of their class.

No more than $15 \%$ of the bondholders could have disagreed with the plan under the New Jersey statute in Asbury Park, and the statute required an independent judicial determination that their interests were fairly considered. Any creditor was entitled to appear before the state supreme court and argue that the plan would treat him unfairly, and the court, before approving the plan, was required to make an independent determination

(1) that the municipality is unable to pay in full according to their terms the claims proposed to be adjusted or composed, and perform its public functions and preserve the value of property subject to taxation, (2) that the adjustment or composition is substantially measured by the capacity of a municipality to pay, (3) that it is in the interest of all the creditors affected thereby, and (4) that it is not detrimental to other creditors of the municipality. ${ }^{219}$

Thus, even with regard to the $15 \%$ of the creditors who might not have approved the plan, the act required an independent judicial determination that the plan was in their interest. This determination did not entail the minimal review of Blaisdell and Flushing. Rather, the Court noted that the plan had been found "wise and just after due hearing"220 and careful scrutiny by the state court. ${ }^{221}$

${ }^{218}$ See text accompanying notes $128-55$ supra.

219316 U.S. at 504 (emphasis supplied).

$220 \mathrm{Id}$. at 514.

${ }^{221}$ Id. at 513, 515. 
Thus, the language in Asbury Park relied on by the Flushing courts, ${ }^{222}$ viewed in context, does not detract from the general theory that a state may not impair its own contracts that involve bargained-for benefits and financial obligations. Rather, Asbury Park involved a situation in which the contract impairments had to be approved by at least $85 \%$ of the adversely affected parties, and in which the interests of the dissenting minority were protected by careful judicial scrutiny. ${ }^{223}$

Although the Asbury Park Court never suggested that such legislation was the only constitutional way for a state to modify a municipality's debt obligations, the New Jersey act does meet the objections to unilateral state action outlined in this Comment, ${ }^{24}$ while at the same time it provides a practical way of dealing with a municipality's fiscal problems. As has been seen, New York's wage freeze and debt moratorium laws, though possibly adequate from New York's point of view, fail to protect adequately the interests of private contracting parties. Accordingly, the Asbury Park situation can provide useful guidance in the search for a more satisfactory solution to the fiscal problems of major cities.

${ }^{222}$ See text accompanying notes 90-96 supra.

${ }^{223}$ Of course, the optimum protection would be afforded by a plan that required the concurrence of $100 \%$ of the creditors. As the Asbury Park Court recognized, however, no agreement by $100 \%$ of the creditors is possible if any one creditor can hold out and thereby secure his paper rights:

Experience shows that three conditions are essential if the municipality is to be kept going as a political community and, at the same time, the utmost for the benefit of the creditors is to be realized: impartial, outside control over the finances of the city; concerted action by all the creditors to avoid destructive action by individuals; and rateable distribution.

316 U.S. at 510 (emphasis supplied). Later, the Court reiterated that the $85 \%$ requirement is necessary "in order to prevent unreasonable minority obstruction." Id. at 513 . As a practical matter, this is certainly correct. As the Court concluded in response to the plaintiffs' contention that the legislation caused the bond's quality to drop below the level of acceptable investments for a rational investor:

Here we have just the opposite-no security whatever except the effective taxing power of the municipality; the effective taxing power of the municipality prostrate without state intervention to revive the famished finances of the city; state intervention, carefully devised, worked out with scrupulous detail and with due regard to the interests of all the creditors, and scrutinized to that end by the state judiciary with the result that that which was a most depreciated claim of little value has, by the very scheme complained of, been saved and transmuted into substantial value. To call a law so beneficent in its consequences on behalf of the creditor who, having had so much restored to him, now insists on standing on the paper rights that were merely paper before this resuscitating scheme, an impairment of the obligation of contract is indeed to make of the Constitution a code of lifeless forms instead of an enduring framework of government for a dynamic society.

Id. at 515-16.

${ }^{224}$ Text accompanying notes 119-55 supra. 


\section{B. A New Constitutional Framework}

This Comment has examined the inadequacies inherent in the courts' use of the minimal Blaisdell standard in reviewing legislation that impairs a state or municipality's own contractual obligations. First, the state, as an interested party to the contract, is in no position to judge impartially what action will satisfy the public interest and at the same time preserve the vested rights of the private contracting parties. In fact, the states' financial problems make it likely that states will often be interested in reducing the amount of their outstanding obligations, regardless of whether less drastic measures would deal satisfactorily with the immediate crisis. Moreover, a state or municipality in the midst of a fiscal crisis cannot be expected to consider the long-run implications of its legislation, much less the consequences for other municipalities. Yet the judicial sanction of legislation like the New York laws at issue here will increase the risk involved in purchasing municipal obligations and, consequently, the cost of selling such obligations, at a time when municipalities are already experiencing difficulties in selling debt.

The relevant inquiry thus centers on the proper scope of review for legislative impairment of a contract under the terms of which the state, as a party, receives direct, bargained-for benefits and is subject in turn to financial obligations. The Supreme Court has demonstrated that it will not read the contract clause so rigidly that all such contract impairments will be prohibited. $^{225}$ Indeed, the Blaisdell standard should probably apply even in some of the cases in which the government is a party to a mutually beneficial contract involving financial obligations. ${ }^{26}$ For example, reasonable alterations of contract terms that are not of primary consideration for the buyer's undertaking will be allowed, "provided no substantial right secured by the contract is thereby impaired."227 That the distinction between remedy and substance may no longer be valid ${ }^{228}$ probably

${ }^{225}$ See, e.g., El Paso v. Simmons, 379 U.S. 497 (1965).

226 There are other situations in which the Blaisdell standard applies even though the state is a party to the contract. For example, the Blaisdell standard-not the contract clause policies set forth in this comment-applies when the government's contractual obligation constitutes a part of a larger class of contracts impaired by general legislation or when the state grants a privilege subject to an implied reservation of the police powers, as in the charter-license cases. See text accompanying notes 155-71 supra.

${ }^{227}$ Von Hoffman v. City of Quincy, 71 U.S. (4 Wall.) 535, 553 (1867). See El Paso v. Simmons, 379 U.S. 497 (1965).

${ }^{228}$ See El Paso v. Simmons, 37؟ U.S. 497, 506 (1965); W.B. Worthen Co. v. Kavanaugh, 295 U.S. 56, 60 (1935). 
means that any reasonable modification that does not affect substantial contract rights will be held unconstitutional. ${ }^{229}$ Certainly when a court determines that the rights of a private party under a contract and the value of the contract to that party are not affected, reasonable legislation modifying the contract provision for the benefit of the state does not contravene the policies of the contract clause. ${ }^{230}$ Likewise, legislation that merely involves modifications of minor terms that are not central to the contract or modifications that are tailored to preserve substantial contract rights probably does not warrant strict review. ${ }^{231}$

In none of these situations, in which the Court probably would apply the Blaisdell standard-and would be justified in doing so-does the legislative impairment involve a substantial modification of a term that is central to the contract. This Comment has argued, however, that in situations, such as that in New York, in which the impairment does substantially modify a term that is central to a government contract, the Blaisdell standard of review becomes constitutionally inadequate, and a different scope of review is mandated.

The appropriate constitutional approach in such situations is suggested by the legislative solution to the New Jersey crisis in Asbury Park. The New Jersey statute required, among other things, that the private parties to the contract at issue participate in the formulation of the plan-and that a substantial number of them approve it-and that the state judiciary carefully scrutinize the plan to ensure that it is in the best interest of those bond-

${ }^{229}$ See, e.g., EI Paso v. Simmons, 379 U.S. 497, 506-09 (1965).

${ }^{230}$ See United States Trust Co. v. State, 134 N.J. Super. 124, 338 A.2d 833 (1975), aff' $d, 69$ N.J. 253, 353 A.2d 514 (1976). In that case, the court upheld a state statute that repealed a 1962 New York-New Jersey covenant limiting the use of Port Authority revenues for mass transit. The repeal prevented Port Authority bondholders from enforcing the convenant, which had been in effect when the bonds were purchased. The court found that " $[t]$ he claim that bondholder security has been materially impaired or destroyed by the repeal is simply not supported by the record." Id. at 196, $338 \mathrm{~A} .2 \mathrm{~d}$ at 874. The court noted that millions of dollars worth of the same bonds had been purchased after the repeal of the covenant and that the bonds continued to receive excellent investment ratings after the repeal. As a factual matter, the court may have been incorrect in finding that use of Port Authority funds for mass transit would not decrease the security of the bonds. See Kraft \& St. John, The Contract Clause as the Guardian Against Legislative Impairment of Municipal Bondholders' Rights, 6 SETON HALL L. REv. 48, 78-81 (1974). Furthermore, it is not clear that the court considered this finding to be crucial to its decision. If the finding was correct, however, and was relied on by the court, this case presents a good illustration of the type of contract impairment that should not be held to violate the contract clause, even when the state is a party to a mutually beneficial contract involving financial obligations.

${ }^{231}$ The Simmons Court characterized the legislation at issue in this way. 379 U.S. at 514-15. See text accompanying notes 201-04 supra. 
holders who did not approve it. Such an approach is consistent with the policies of the contract clause. ${ }^{232} \mathrm{~A}$ judicial analog to this type of legislation is a less-restrictive-alternatives test.. ${ }^{233}$ Under this type of review, the courts would be required to scrutinize carefully any legislation impairing the obligations of government contracts with private parties. The legislation would be upheld only upon an independent judicial determination (1) that the municipality has no viable alternative to modifying the contract terms and that there is a compelling public interest in the legislation, (2) that whatever contract impairment is allowed goes no further than is required by the municipality's needs and (3) that to the greatest extent possible the financial interests and contract rights of the private parties are preserved. Under this type of judicial review, the wage freeze would likely be held unconstitutional for several reasons. First, there was never any showing that the city was unable to pay the $\$ 100-200$ million in wages estimated to be saved under the law. Second, even if the city had an irremediable shortage of funds, it had the option of discharging employees it could not afford to keep; or, to the extent that such action would not be in the unions' interest, a voluntarily negotiated settlement could have been reached. Furthermore, even if the court found that there was no money to pay for this wage increase and that the maintenance of city services at their present level was of such compelling public importance that no employees could be discharged, the court still could have required the city to issue to its employees debt obligations with accruing interest for unpaid wages. This less restrictive alternative, while preserving to the greatest extent possible the rights of the municipal employees, would have satisfied the city's immediate need for the $\$ 100-200$ million.

Similarly, New York's Moratorium Act would be unable to survive the type of judicial scrutiny proposed here. Assuming that a court had determined that New York was unable to pay its notes as they accrued and that there was no viable alternative to some form of moratorium, it still should have upheld only a law that ensured that the interest rate paid on the unredeemed notes reflected the cost to the noteholders of the forced investment.

${ }^{232}$ See notes 25-38 supra \& accompanying text.

${ }^{233}$ See, e.g., Pike v. Bruce Church, Inc., 397 U.S. 137, 142 (1970); Shelton v. Tucker, 364 U.S. 479, 488-90 (1960); Dean Milk Co. v. City of Madison, 340 U.S. 349, 354-56 (1951); Schneider v. State, 308 U.S. 147, 164 (1939). In all of these cases, the Caurt considered the possibility of alternative, less burdensome solutions to be one factor in the determination of the validity of state or city laws that infringe upon constitutional values. 
Thus, the legislation should be required to provide for a negotiated interest rate and moratorium period acceptable to, for example, $85 \%$ of the noteholders. If no agreement could be reached, the legislation should require the dispute to be submitted to an independent arbitrator. If the parties still failed to reach a satisfactory settlement, the court, as a last resort, might itself set an interest rate that reflected the risk of the investment. The $6 \%$ interest rate provided in the Moratorium Act clearly did not represent an attempt to preserve as nearly as possible the original contract rights of the noteholders. Furthermore, to pass constitutional muster, moratorium legislation should be required to provide for payment of principal, as notes mature, to small investors who can show special need, as suggested by the New York Supreme Court in Flushing. ${ }^{234}$ With respect to all of these requirements, the New York measure was lacking.

\section{Conclusion}

The minimal standard of review of contract impairments set forth in Home Building $\mathcal{E}^{2}$ Loan Association v. Blaisdell ${ }^{235}$ is inappropriate for reviewing unilateral legislative impairments of government contracts. The policies of the contract clause require that the courts play a strict, activist role in overseeing such contract impairments. Strict scrutiny is essential to ensure that state and local governments, which are not impartial when they are parties to contracts, cannot wield such power as to make their obligations meaningless. A strict standard of review based on a less-restrictive-alternatives analysis would allow governments to have the necessary flexibility of action when compelling reasons exist for modifying their contractual obligations, and at the same time preserve, to the greatest extent possible, the financial interests of the private parties to the contracts. By promoting the confidence of investors and other government contractors that their contracts will be enforced scrupulously by the state courts, unless there is absolutely no feasible way to avoid the impairment, such a judicial posture would play an essential role in safeguarding the fiscal stability of municipalities.*

${ }^{234}$ See text accompanying note 31 supra.

235290 U.S. 398 (1934).

* On Nov. 19, 1976-after this Comment went to press-the New York Court of Appeals reversed the Appellate Division's decision in Flushing, holding the debt moratorium and wage freeze violative of the state constitution's provision requiring the city to pledge its "faith and credit" for the payment of the principal of any indebtedness for which it contracts. N.Y. Times, Nov. 20,1976, at 14, col. I (N.Y. Nov. 19, 1976). The court did not reach the contract clause question under the Federal Constitution. 